\title{
A responsabilidade civil do Estado pelo exercício da função jurisdicional no Brasil
}

Estudo em memória do Prof. Clóvis Veríssimo do Couto e Silva

Ruy Rosado de Aguiar Júnior

Desembargador

Mestre

La responsabilidad de jueces y magistrados se está convertiendo, día a día y a pasos agigantados, en uno de los temas de atención preferente en el mundo jurídico de todos los países que tienen, o quieren tener, una magistratura independiente.

Juan Montero Aroca

\section{SUMÁRIO}

Introducão $1^{1}$ Parte - A evolução do sistema de responsabilidade civil do Estado no Brasil; 1 - A responsabilidade

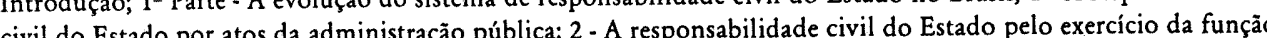
civil do Es 1 a par apresentadas; 2 - A interpretação das normas legais vigentes; 3 - As características do sistema proposto; Conclusão.

\section{Introdução}

Enquanto se desenvolve e amplia a doutrina da responsabilidade civil da administração pública em geral, o tema da responsabilidade por fato da justiça continua, no Brasil, a merecer aplicação restrita, em desacordo com as aspirações do Estado moderno, o que contribui, de certo modo, para a despreocupação com o aperfeiçoamento dos serviços judiciários e simplificação dos procedimentos.

Pretende-se, no presente trabalho, apresentado ao Tercer Congreso Internacional de Derecho de Daños - Buenos Aires, maio/1993, fazer breve descrição da responsabilidade civil do Estado em geral, e por fato da justiça, em particular, assim como evoluiu no Brasil e se caracteriza no presente, com informações do Direito de países que, ultimamente, modificaram seus princípios, concluindo por apresentar o sistema que se entende aplicável, de acordo com o direito vigente.

\section{I - A evolução do sistema de} responsabilidade civil do Estado

No Brasil, convém iniciar o estudo da responsabilidade civil do Estado pelo exercício da função jurisdicional com o breve resumo da evolução do conceito mais amplo e abrangente da própria responsabilidade civil do Estado. Enquanto esta passou da irresponsabilidade absoluta da Fazenda Pública (admitida apenas a pessoa do funcionário) para a responsabilidade direta e objetiva do Estado (com direito de regresso contra o funcionário culpado), a idéia da responsabilidade estatal por ato jurisdicional pouco avançou na lei e na aplicação dos tribunais, apesar do hoje majoritário apoio da doutrina, preponderantemente favorável à sua plena incidência.
1. A responsabilidade civil do Estado por atos da administração pública

1.1. Com a independência em 1822, a Constituição Imperial de 1824 estatuiu: "Os empregados públicos são estritamente responsáveis pelas obras e omissões praticadas no exercício de suas funções, e por não fazerem efetivamente responsáveis os seus subalternos" (art. 178, item 29).

Esse preceito figurava no artigo que dispunha sobre os direitos políticos fundamentais, o que levou Pimenta Bueno, um dos seus mais autorizados comentadores, a enfatizar a circunstância de que a responsabilidade do servidor público ingressou em nosso ordenamento constitucional como uma garantia básica do cidadão'.

Adotava-se a teoria regaliana, de irresponsabilidade do Estado, segundo a qual não se pode conceber o Estado aposto prática de atos ilícitos; se estes ainda assim acontecem, são condutas de funcionários culpados e só a eles, a título de culpa ou dolo, podem ser imputados.

1.2. Logo após a proclamação da República (1889), o governo editou dois diplomas que nos interessam: o Dec. 451-B, de 31.5.1890, dispondo sobre o Registro Torrens, e o Dec. 847, de 11.10.1890, publicando o novo Código Penal. Naquele estabeleceu a obrigação da Fazenda Pública de indenizar os danos que alguém sofresse em conseqüência da indevida inscrição de imóvel ou direito real seu em nome ou em favor de outrem (art. 61). O Código Penal, ao tratar da reabilitação, atribuiu ao Estado a responsabilidade direta pelos danos decorrentes de erro judiciário reconhecido em sentença de reabilitação ${ }^{2}$. Em ambos os casos, o Estado foi colocado diretamente em confronto com o lesado, como devedor da obrigação e legitimado passivo na ação de indenização.

A Constituição Republicana de 1891 não seguiu nessa linha, limitando-se a repetir o princípio geral já expresso na Constituição Imperial: "Os funcionários públicos são estritamente responsáveis pelas obras e omissões que incorrerem no exercício de seus cargos, assim como pela indulgência ou negligência em não responsabilizarem efetivamente os seus subalternos" (art. 82)

O legislador infraconstitucional, porém, continuou tratando da responsabilidade direta do Estado. A Lei 221, de 20.11.1894, regulamentou os procedimentos: "Art. 13. Os juízes e tribunais federais processarão e julgarão as causas que se fundarem na lesão de direitos individuais por atos ou decisões das autoridades administrativas da União"3.

O Dec. Legislativo 1.151, de 5.1.1904, reorganizando o serviço federal de higiene, dispôs: "Fica salvo à pessoa lesada o direito de reclamar judicialmente, perante a justiça federal, as perdas e danos que lhe couberem, se $o$ ato ou a medida da au toridade sanitária tiver sido ilegal, e promover a punição penal, se houver sido criminosa".

Tirante os casos excepcionais de réu reabilitado, de lesado por ato ilegal da autoridade sanitária e da falha do serviço de Registro Torrens, prevalecia o entendimento de irresponsabilidade do Estado ${ }^{4}$. Os demais atos ilegais, observa Alcino de Paula Salazar, seriam anulados ou não se thes daria aplicação, mas a declaração de nulidade ou de ineficácia não acarretaria a reparação dos danos resultantes. Cita, para exemplificar essa orientação, a "Nova Consolidação", de Carlos de Carvalho (1898), onde constava: Art. 1.021, § 1ํ - "A União não responde pelos danos provenientes de erros ou abusos de funcionários ou empregados públi$\cos ^{\prime \prime}$

1.3. A $1^{\circ}$ de janeiro de 1917 entrou em vigor o Código Civil, que aceitava, no tema genérico da responsabilidade civil, a teoria da culpa ${ }^{5}$. Em seu artigo 15, fazendo aplicação dessa teoria ${ }^{6}$ e mais a da represen tação (o funcionário é o representante do ente estatal), assumiu claramente a posição favorável à responsabilidade direta (isto é, primária) $)^{7}$ do Estado: "Art. 15 - As pessoas jurídicas de direito público são civilmente responsáveis por atos dos seus representantes que nessa qualidade causem danos a terceiros, procedendo de modo contrário ao direito ou faltando a dever prescrito por 
lei, salvo o direito regressivo contra os causadores do dano" 8 .

Essa disposição legal veio reforçar a corrente, que nunca deixara de existir e que se tornava cada vez mais numerosa, daqueles que defendiam a ampla responsabilidade do Estado por atos de seus servidores, vista como idéia-força do Estado moderno.

Rui Barbosa, por diversas vezes, posicionou-se favoravelmente à reponsabilidade do Estado, sustentando que a pessoal prevista no artigo $32 \mathrm{da}$ Constituição de 1891 não excluía a do Estado'. Aceitar a irresponsabilidade da Fazenda Pública, doutrina "hoje repudiada pelos juristas", seria descurar da fecunda revolução jurídica que se estava realizando nos demais países, afirmava Pedro Lessa, com sua autoridade de mestre do Direito e ministro do Supremo Tribunal Federal $^{10}$. Amaro Cavalcanti, que escreveu em 1905 alentada monografia sobre a responsabilidade civil do Estado, dava ao artigo 82 da Constituição de 1891 abrangência limitada aos seus termos: o dispositivo afirmava a responsabilidade do funcionário por suas faltas, mas não impedia a coexistência da responsabilidade estatal, de forma principal, solidária ou subsidiária, conforme o caso ${ }^{11}$.

A jurisprudência do STF passou da total negativa (a Fazenda Pública não responde pelas faltas dos seus funcionários) ${ }^{12}$, à acei tação irrestrita do princípio (é indisputável a responsabilidade civil do Estado pelos danos causados aos particulares pelos funcionários públicos) $)^{13}$. Em certo momento, fezse uma distinção (1921-1924): o Estado não responderia se o ato do funcionário fosse criminoso, quando a responsabilidade seria pessoal ${ }^{14}$. A partir de 1932, porém, voltou a prevalecer a tese mais ampla ${ }^{15}$

1.4. Com a revolução de 1930 , o governo expediu o Dec. 24.216, de 9.5.1934, do seguinte teor: "A União Federal, o Estado ou - Município não respondem civilmente pelos atos criminosos de seus representantes, funcionários ou prepostos, ainda quando praticados no exercício do cargo, função ou desempenho dos seus serviços, salvo se neles forem mantidos após a sua verificação". 18
Como o $\S 1^{\circ}$ impunha o dever de demitir o funcionário faltoso, a hipótese da responsabilização do Estado, nesses casos, praticamente desapareceu.

Logo após, porém, em 16 de julho de 1934, foi promulgada a Constituição Federal, que admitiu a responsabilidade direta $e$ solidária do Estado, sem ressalvar a natureza criminosa do fato: "Art. 171. Os funcionários públicos são responsáveis solidariamente com a Fazenda Nacional, Estadual ou Municipal, por quaisquer prejuízos decorrentes de negligência, omissão ou abuso no exercício de seus cargos". A Constituição de 1937, instituindo o regime totalitário do "Estado Novo", repetiu a mesma regra.

1.5. A grande novidade veio com a Constituição de 1946, promulgada logo após a redemocratização do país, mantendo o princípio da responsabilidade direta do Estado e acolhendo a teoria objetiva: "Art. 194. As pessoas jurídicas de direito público interno são civilmente responsáveis pelos danos que seus funcionários, nessa qualidade, causarem a terceiros. Parágrafo único. Caber-lhes-á ação regressiva contra os funcionários causadores do dano, quando tiver havido culpa destes". A Constituição de 1967 (art. 105), bem como a Emenda de 1969 (art. 107), não introduziram alteração substancial: "Art. 107: As pessoas jurídicas de direito público responderão pelos danos que seus funcionários, nessa qualidade, causarem a terceiros. Parágrafo único. Caberá ação regressiva contra o funcionário responsável, nos casos de culpa ou dolo".

1.6. A vigente Constituição da República (1988), ao regular a administração pública, dispõe: "Art. $37, \S 60$. As pessoas jurídicas de direito público e as de direito privado prestadoras de serviços públicos responderão pelos danos que seus agentes, nessa qualidade, causarem a terceiro, assegurado o direito de regresso contra o responsável nos casos de dolo ou culpa".

Essa disposição constitucional forneceu as diretrizes para um sistema de responsabilidade civil do Estado no qual apontamos os seguintes aspectos: a) o agente (servidor, empregado ou funcionário) é presentante da pessoa jurídica de direito público, daí que a responsabilidade desta decorre diretamente da ação do agente, como seu órgão, não se caracterizando aí uma responsabilidade transubjetiva, como se o agente fosse o seu representante, ao modo regulado no artigo 15 do Código Civil.

b) o Estado responde sempre que do seu funcionamento regular ou irregular decorrer prejuízo para o terceiro, independentemente de se questionar sobre a existência de culpa do serviço, bastando o fato do serviço. Contudo, haverá exoneração total ou parcial se o órgão público demonstrar culpa exclusiva ou concorrente do lesado ${ }^{16}$.

c) a responsabilidade objetiva se estende aos fatos comissivos. Nos casos de omissão, é preciso distinguir: ou o Estado era obrigado a praticar uma ação e não a presta, dessa omissão resultando imediatamente 0 dano (o Estado deixa de prestar o serviço a que estava obrigado, e a indústria paralisa, sofrendo danos); ou o Estado tinha o dever de evitar o resultado e se omite, sendo o dano provocado diretamente pela ação de terceiro ou fato da natureza (o Estado não garante a segurança do presídio, sendo a vítima morta pela ação do réu foragido; o Estado não limpa os bueiros que a chuva faz transbordar, provocando inundação). No primeiro caso, basta o fato do serviço, a omissão da prestação devida; no segundo, além da omissão, impende demonstrar que o Estado estava obrigado a evitar o resultado danoso, ocupando a posição de garantidor do bem e que concorreu para o resultado através de sua omissão culposa (falta do serviço) ${ }^{17}$.

d) são causas excludentes da responsabilidade do Estado: a culpa exclusiva da víti$\mathrm{ma}^{18}$, o fato de terceiro e a força maior ${ }^{19}$ Não o caso fortuito, porquanto este é "uma causa interna, inerente ao próprio serviço .. será o cabo de uma instalação que se rompe, será a peça de uma máquina que se despedaça"20. Não há igualmente exclusão, quan do o Estado tinha o dever, determinado pelas circunstâncias, de evitar o resultado danoso da ação de terceiro ou de um acontecimento natural e não o cumpriu por fal- ta do serviço ${ }^{21}$. O estado de necessidade não é a causa exonerativa, salvo se a situação de perigo foi posta pelo lesado e o Estado praticou a ação necessária contra ele, provocando-lhe o dano. Nesse caso de estado de necessidade defensivo, o autor do perigo e afinal lesado nada pode reclamar. Nos demais casos de estado de necessidade agressivo, agindo o Estado na defesa de um interesse coletivo para afastar o perigo não criado pela vítima, deve indenizar aquele a quem sua ação causou prejuízo.

e fundamento da responsabilização do Estado reside no princípio da igualdade, que exige harmônica distribuição dos ônus e encargos sociais. Porém, se o ato lesivo é contrário à lei, o princípio que então fundamenta o imputação é o da legalidade ${ }^{22}$.

f) o ponto central de visualização do sistema se deslocou da ação do agente (comportamento lícito ou ilícito) para a consideração da situação da vítima e do dano injusto, o que acentuou o dever de reparação do dano decorrente da atuação do Esta$\mathrm{do}^{23} 24$.

g) a relação entre o Estado e o seu agente é de natureza subjetiva: o Estado terá ação regressiva se houver culpa ou dolo do agente. No exercício e para resguardo desse direito, pode o Estado denunciar a lide ao servidor faltoso ${ }^{25}$.

h) a redação dada ao dispositivo veio superar a antiga disputa sobre a extensão dos princípios da responsabilidade objetiva às empresas de direito privado que desempenhavam serviços públicos. A noção central, agora, reside no conceito de "serviço público", pouco importando a natureza da pessoa jurídica.

i) a denominação mais aceita para o instituto continua sendo a de responsabilidade civil do Estado, apesar da resistência dos publicistas $^{26}$

\section{A responsabilidade civil do Estado} pelo exercício da função jurisdicional

2.1. Ao tempo do Brasil colônia, vigoravam as Ordenações do Reino de Portugal e suas leis' complementares e extravagantes. 
As primeiras, as Ordenações Afonsinas, mandadas publicar por Afonso V em 1446, constituíram importante expressão de unitarismo e centralismo jurídicos ${ }^{27}$, reunindo em texto dividido em cinco livros as normas sobre os diversos ramos do Direito Consolidavam leis promulgadas pelos seus antecessores, inspirando-se no Direito Romano, no Direito Canônico, no Fuero Juz go e na Lei das Siete Partidas ${ }^{28}$. Pouco mais de meio século depois, seguiram-lhes as Ordenações Manuelinas (1521) e, em janeiro de 1603, as Ordenações Filipinas, que vigoraram em Portugal até 1867 e, no Brasil, por mais de trezentos anos, até a vigência do Código Civil, em 1917.

As ordenaçōes Filipinas adotaram o prin cípio da responsabilidade pessoal do juiz, do que se recolhem diversas passagens: $\mathrm{Li}$ vro I, Título LXXXVIII, $\S 16$ - "... e o juiz que isto não cumprir, pagará ao órfão toda a perda e dano que por isso se lhe causar", Livro III, Título LXII, § $5^{\circ}$ - "... e o julgador, que os tais atos processou, será obrigado às custas no caso, que processou sem citação, ou com citação nula"; Livro IV, Título CII, 70 - "E faça o dito juiz de tal maneira, que po sua culpa ou negligência os bens dos órfãos não recebam dano, porque todo o dano perda que receberem pagará por seus bens".

A fim de garantir essa responsabilidade pessoal, a exemplo do que ocorria na Espanha ${ }^{29}$, era 0 juiz obrigado a dar residência, com o dever de permanecer por certo tempo no lugar onde exercera a função, para responder às reclamaçōes dos eventuais lesados. Para isso, o novo juiz do lugar, nos dez dias seguintes à sua posse, deveria proceder à devassa sobre o juiz anterior, a chamada "janeirinha", regulada nas Ordenações Filipinas, Livro I, Título LXV, §§ 39 a 72, enviando seu resultado ao corregedor da coroa ${ }^{30}$

2.2. Após a independência, não se alterou esse quadro, silenciando a Constituição de 1824 sobre a responsabilidade dos juízes. O importante Decreto 737, de 25.11.1850, dispondo sobre a ordem do juízo no processo, previa a responsabilidade pessoal do juiz ${ }^{31}$

A novidade aconteceu com a promulgação do Código Penal de 1890 , que impôs ao
Estado o dever de indenizar o réu condenado por sentença criminal e depois reabilitado. Por força desse preceito legal é que Pedro Lessa, embora partidário da irresponsabilidade do Estado por ato jurisdicional, admitiu "nos casos de revisão ou rescisão da sentença ... podem os particulares obter o ressarcimento do prejuízo infligido por uma sentença ilegal" ${ }^{132}$.

O Código Civil de 1917, além da regra do artigo 15, já referido, estabelecendo a responsabilidade das pessoas jurídicas de direito público por atos dos seus funcionários, contém inúmeros preceitos que impõem diretamente ao juiz a responsabilidade pelos danos causados às partes, como se vê dos artigos $294,420,421$ e $1552^{33}$.

2.3. A partir de 1940 , foram editadas as novas codificações: Código Penal, Código de Processo Penal e Código de Processo Civil.

O Código Penal de 1940, ainda hoje em vigor, com alterações, depois de enunciar diversos delitos que podem ser praticados pelos funcionários públicos (entre eles incluídos os juízes), como o peculato, concussão, corrupção, prevaricação, etc., previstos nos artigos 312 a 317), definiu o crime de exercício arbitrário ou abuso de poder: "Art. 350. Ordenar ou executar medida privativa da liberdade individual, sem as formalidades legais ou com abuso de poder". Posteriormente, a Lei 4.898 , de 9.12.1965, que tratou da responsabilidade civil, administrativa e penal nos casos de abuso de autoridade, definiu como tal "deixar o juiz de ordenar o relaxamento de prisão ou detenção ilegal que lhe seja comunicada" (art. 4º, "d"), sujeitando-o, além de outras sanções, à reparação civil do dano (art. $6^{\circ}, \S 2^{\circ}$ ).

O Código de Processo Penal (1942), igualmente ainda em vigor, tratou da indenização do erro judiciário, atribuindo essa responsabilidade diretamente ao Estado, condicionando-a não mais à reabilitação do réu, mas à revisão da sentença condenatória ${ }^{34}$.

O atual Código de Processo Civil (1973), repetindo a regra já constante do CPC de 1939, dispõe: "Art. 133. Responderá por perdas e danos o juiz, quando: I - no exercício de suas funções, proceder com dolo ou fraude: II - recusar, omitir ou retardar, sem justo motivo, providência que deva ordenar de ofício; ou a requerimento da parte. Parágrafo único. Reputar-se-ão verificadas as hipóteses previstas no $\mathrm{n}^{\circ}$ II só depois que a parte, por intermédio do escrivão, requerer ao juiz que determine a providência e este não the atender o pedido dentro de dez (10) dias".

A Lei Orgânica da Magistratura (Lei Complementar $\mathrm{n}^{\circ} 35$, de 14.3.1979) reproduziu tal enunciado em seu artigo 49 , estendendo sua incidência também aos atos praticados nas demais jurisdições (criminal, eleitoral, trabalhista, militar) ${ }^{35}$. Esta lei, que também é o estatuto da magistratura nacional, regula a hipótese de aposentadoria do juiz por negligência manifesta e incapacitação para o serviço (art. 56) ${ }^{36}$

As Constituições Federais de 1946, 1967 e a Emenda $\mathrm{n}^{\mathrm{0}} 1$, de 1969, nada disseram quanto à responsabilidade do juiz.

A Constituição de 1988, no título dos direitos e garantias fundamentais, contém a seguinte norma: "Art. 5, alínea LXXXV - O Estado indenizará o condenado por erro judiciário, assim como o que ficar preso além do tempo fixado na sentença".

Em resumo, coexistem no Brasil, sobre o tema, os seguintes preceitos constitucionais e legais: Constituição de 1988, artigo 50, alínea LXXXV, e artigo 37, § $6^{\circ}$; Código Civil de 1917, artigos 15, 294, 420, 421 1.551; Código Penal de 1940, artigos 312 a 317 e 350; Código de Processo Penal de 1941, artigo 630; Lei 4.898/65; Código de Processo Civil de 1973, artigo 133; Lei Orgânica da Magistratura (LOMAN) de 1979 artigos 49 e 56.

2.4. Diante desse quadro legislativo, orientação jurisprudencial predominante até aqui tem afirmado a irresponsabilidade do Estado por atos dos juízes, salvo quando o dever de indenizar é expressamente previsto em lei, como ocorre no erro judiciário criminal, após processo de revisão (art. 630 do CPP).

A negativa encontra fundamento nas teses universalmente difundidas sobre o tema ${ }^{37}$. Três delas são apresentadas com maior ênfase: a soberania exercida pela autoridade judiciária; a força da coisa julgada e a necessidade de garantir a liberdade e a independência dos juízes.

Estado não responderia pelo ato jurisdicional porque emanação da própria soberania, supra legem, de cujo exercício não pode surgir pretensão ressarcitória. Decidiu o Supremo Tribunal Federal, em sessão plenária: "O Estado não é civilmente responsável pelos atos do Poder Judiciário, a não ser nos casos expressamente declarados em lei, porquanto a administração da justiça é um dos privilégios da soberania" ${ }^{38}$. E, mais recentemente,: "O pensamento dominante é de que, em se tratando de exercício de atos de soberania, a igual da responsabilidade do legislador, não poderia resultar a responsabilidade de indenizar quem, súbito, sofresse prejuízos daí conseqüentes ${ }^{1139} 40$. Como conseqüência dessa asserção, o juiz não seria funcionário ou preposto do Estado; logo, se houvesse ilicitude, esta seria da responsabilidade exclusiva e pessoal do seu autor, nos termos da lei (CPC, CC, Loman).

O segundo obstáculo reside na existência da coisa julgada: "A irresponsabilidade do poder público neste caso é um corolário fatal da autoridade da res judicata ${ }^{\prime \prime 1}$. A coisa julgada, tida como expressão da verdade (res judicata pro veritate babertur, Ulpiano, D. 12.2.3.1), é instituto processual especialmente importante para a segurança das relações sociais, e a imutabilidade das decisões judiciais tem relevância social preponderante.

Por fim, a abalo à independência do julgador: "A irresponsabilidade do Estado pelos atos e omissões dos juízes advém da independência da magistratura, prerrogativa esta que tem como conseqüência lógica o tornar exclusivamente pessoal a responsabilidade ${ }^{\prime 42}$. No Supremo Tribunal Federal afirmava-se: "Domina, pois, nesse âmbito, o princípio da irresponsabilidade, não só em atenção à autoridade da coisa julgada como também à liberdade e independência dos magistrados, que se sentiriam tolhidos, a cada passo; na sua função de dizer o direito ou resolver as graves questões administrati- 
vas que lhe são afetas, pelo temor de engendrar responsabilidade, para si e para o Estado que representam"43.

As manifestações judiciárias em sentido diverso são escassas ${ }^{44}$.

A doutrina, até meados deste século, bateu sempre na mesma trilha: o ato jurisdicional é emanação da soberania, se reveste da força incontrastável da coisa julgada, não ofende a direitos subjetivos e não gera a responsabilidade civil do Estado ${ }^{45}$.

2.5. Nos últimos anos, porém, está surgindo movimento vigoroso em favor da ampliação do conceito, por motivos de ordem política e razões de ordem jurídica. Do ponto de vista político, porque a marcha para a plena realização do Estado de Direito aspiração que a todos deve orientar - impõe a gradual extinção da idéia da irresponsabilidade, quando resquício de privilégios antes concedidos a classes e pessoas para a mantença de poderes e benefícios injustificáveis à luz do Estado moderno, democrático, igualitário e solidário. Juridicamente, porque o ato estatal praticado através do juiz não se distingue ontologicamente das demais atividades do Estado, estas geradoras do dever de indenizar uma vez presentes os requisitos. Isto é, o Estado-Juiz é uma fração do Poder Público que pode, através de seu agente, nessa qualidade, causar dano injusto, não havendo razão jurídica para impor ao lesado o sofrimento do prejuízo daí decorrente. A necessidade de realizar a justiça material, finalidade que deve presidir o sistema jurídico estatal, não se satisfaz com o sacrifício individual injusto, mesmo quando conseqüência do ato jurisdicional. Talvez aí, e por isso mesmo, ainda maior o sentimento de inconformidade, pois o objtivo da jurisdição é realizar a justiça.

As primeiras e mais destacadas manifestações a favor da responsabilização do Estado por ato dos juízes encontramos ainda na década de 40, na monografia de Alcino de Paula Salazar, "Responsabilidade do Poder Público por Atos Judiciais", e na obra clássica do direito brasileiro, "Da Responsabilidade Civil", de José de Aguiar Dias. O primeiro, após examinar e rebater as objeções feitas ao princípio da responsabilidade, conclui: I - pela responsabilidade do Estado em conseqüência do funcionamento do serviço público, por atos de qualquer natureza, sendo fundamento dessa responsabilidade a idéia solidarista da equitativa distribuição dos ônus e encargos públicos; II - este princípio geral se aplica também aos atos judiciais, com exceção da coisa julgada, que entende deva ser primeiramente desfeita através de revisão ou rescisão ${ }^{46}$. Aguiar Dias, admitindo estar em minoria, sustenta enfaicamente, diante do nosso direito positivo, a responsabilidade do Estado por atos jurisdicionais, modo de garantir a plena satisfação do princípio da igualdade perante a lei de cuja violação surge o direito amplo à indenização, nela incluída a reparação do dano moral, com o que rebate, a um só tempo, quem sustenta ser o dever de reparar mero imperativo do dever de assistência social (Rocco) e ainda contraria a redução do dano indenizável ao seu componente patrimonial. Afirma, ainda, ser indenizável o dano resultante de prisão preventiva injustificada $^{47}$

Desde então, e cada vez com maior uniformidade, inúmeros e valiosos trabalhos doutrinários, expostos em monografias e artigos, passaram a acolher o princípio da responsabilidade do Estado por atos danosos praticados no exercício da função judi$\mathrm{cial}^{4849}$.

\section{Informações de direito comparado}

3.1. Alguns anos após a promulgação da Constituição Italiana de 1947, com a abertura proposta pelo artigo 28 , desenvalveu-se intenso debate sobre o papel e a responsabilidade do juiz na sociedade moderna, caracterizadas as décadas 70/80 pelo "difícil equilíbrio entre o velho e o novo", de uma parte impulsionados pela proposta constitucional, de outra condicionados por uma legislação defeituosa ${ }^{50}$. Nos anos 70 , organizaram-se diversos congressos sobre o tem 52. Em 1988, finalmente, foi publicada a Lei 117, de 13.4.1988, que dispôs sobre o ressar- cimento dos danos causados no exercício da função judiciária e responsabilidade civil do magistrado. É o mais recente diploma que trata de forma abrangente do tema e traça as linhas de um sistema orgânico da responsabilidade do Estado por ato do juiz, cujas características principais são as seguintes:

a) o Estado responde pelo dano causado por dolo, culpa grave ou denegação de justiça. Constitui culpa grave a violação de lei por negligência inescusável, a afirmação ou a negação de fato, por negligência inescusável, contrariamente ao contido nos autos; ordem de privação de liberdade fora dos casos legais ou sem motivação. Caracteriza denegação de justiça a recusa, omissão ou o retardo do magistrado em praticar ato de seu ofício quando, após o término do prazo legal, a parte tenha requerido a providência, decorrendo inutilmente, sem motivo justificado, trinta dias da data do depósito do pedido em cartório. Esse prazo se reduz para cinco dias, em se tratando de privação de liberdade;

b) o magistrado e o Estado respondem pelo dano conseqüente de crime cometido pelo magistrado no exercício de sua função;

c) em ambos os casos, o Estado tem ação regressiva contra o magistrado, cujo valor não pode exceder a um terço da anualidade líquida percebida pelo magistrado ao tempo em que fora proposta a ação de ressarcimento. Tal limite não se aplica ao fato cometido com dolo;

d) o juiz cujo comportamento se examina na ação de indenização não pode ser chamado à causa, mas nela pode intervir em qualquer fase ou grau, pelo que deve ser comunicado da primeira audiência;

e) a ação contra o Estado deve ser proposta contra o Presidente do Conselho de Ministros, no tribunal do lugar onde tem sede a corte de apelação do distrito mais próximo àquele ao qual pertencia o magistrado, no momento do fato;

f) somente pode ser proposta a ação quando esgotados os meios ordinários de impugnação, e no prazo decadencial de dois anos.
3.2. No direito inglês vigorava desde 1613 o princípio da absoluta imunidade judicial pelos atos praticados dentro dos limites da jurisdição intra vires, não ficando excluída a responsabilidade pelos atos ultra vires. Como sempre foi respeitado o princípio de que cabe aos juízes dos tribunais superiores determinar o âmbito da sua jurisdição, e como eles, julgando certa demanda, estão implicitamente admitindo a sua competência ${ }^{53}$, a conseqüência prática é de que sempre o juiz da corte superior praticava atos intra vires e, portanto, ao abrigo da, judicial immunity, ainda que agindo com dolo ou culpa. Para os juízes das cortes inferiores, que não têm o privilégio de determinar o âmbito da própria jurisdição, vigorava plenamente o princípio, com sua responsabilização nos atos praticados ultra vires, cuja prática significava indesculpável erro de direito.

No caso Sirros x Moore $(1974)^{54}$, pelo voto de Lord Denning ${ }^{55}$, ficou de lado o princípio da gradação da imunidade em razão do status da corte, estabelecendo-se que, seja juiz de corte superior ou inferior, ambos devem estar protegidos da mesma maneira, pois o que interessa é tenha ele agido de boa fé. No caso, não foi reconhecida a procedência da ação indenizatória promovida contra o juiz de corte inferior a que se atribuía a prática de ato fora da jurisdição, porque ele agira de boa fé no exercício de sua atividade judiciária, ainda que seu ato tenha sido fruto de um erro e declarado ilegítimo ${ }^{56}$. Podia o juiz estar errado, mas àcreditando honestamente ter agido dentro da sua jurisdição, ele não é responsável ${ }^{57}$. Mais recentemente, porém, no caso In Re MCC (A MInor), 1985, a Câmara dos Lordes não seguiu esse caminho, parecendo ter fracassado o propósito de generalizar a responsabilidade por má-fé, o que dependeria de lei aprovada pelo parlamento ${ }^{58}$.

3.3. Durante o período feudal, na França, o sistema se caracterizava pela privatização das funções estatais, entre elas a da magistratura, para a qual vigorava o princípio da venalidade do cargo, considerado este como um bem de propriedade do ma- 
gistrado e transferivel inter vivos ou causa mortis, pelo que a responsabilidade dos juízes era vista como uma responsabilidade profissional ${ }^{59}$. Com a ascensão da realeza e fruto da criação jurisprudencial, surgiu a partir de 1521 o instituto da prise à partie, procedimento para a responsabilização pessoal dos juízes pelos danos cometidos no exercício da função, cabível quando houvesse dolo, fraude, concussão ou erro evidente de fato ou de direito, regulado substancialmente pela Ordenação de Luiz XIV, de 1667. Com a revolução, tratou-se de organizar um sistema burocrático-judiciário, num momento histórico caracterizado pela desconfiança do legislador para com os juízes, que chegaram a ser proibidos de interpretar a lei e ficaram submetidos hierarquicamente ao governo. $O$ juiz tornou-se responsável apenas nos casos expressos em lei, havendo necessidade de autorização prévia para o processo. A lei de 8.6.1895, modificando o art. 446 do código processual criminal, instituiu regime indenizatório, a cargo do Estado, em favor do condenado declarado inocente em processo de revisão. Em 1933, pela lei de 7 de fevereiro, foi alterada a redação do artigo 505 do código processual civil, admitindo a prise à partie nos casos de dolo, fraude, concussão ou falta grave profissional, no curso da instrução ou do julgamento; admitiu, também, a responsabilidade subsidiária do Estado. A falta grave seria a praticada sob a influência de erro tão grosseiro que um magistrado, se tivesse tido o normal cuidado para com seus deveres, não poderia cometer ${ }^{60}$

Em 1956, no Arrêt Giry, a Corte de Cassação admitiu a responsabilidade do Estado em hipóteses não previstas na legislação, fundamentando-se a decisão em princípio geral do direito público ${ }^{61}$.

A lei 70/643, de 17.7.1970, introduziu no Código Processual Penal a regulação da responsabilidade do Estado pelos danos causados por prisão preventiva, prescrevendo uma indenização a favor do preso absolvido, quando da detenção derivasse dano manifestamente anormal e de particular gravidade.
A Lei de 5 de julho de 1972, no seu artigo 11, atribuiu ao Estado a obrigação de reparar o dano causado pelo funcionamento defeituoso da justiça em razão de falta grave $^{62}$ ou denegação de justiça. A responsabilidade dos magistrados ordinários, por falta pessoal, rege-se pelo estatuto da magistratura, e a dos demais, por lei especial aparecendo o Estado apenas como garantidor dessá responsabilidade. A lei orgânica de 18 de janeiro de 1979 incluiu no estatuto dos magistrados um artigo onde explicita que os da jurisdição ordinária respondem somente pela sua culpa pessoal, mas a ação de responsabilidade contra o magistrado não pode ser exercitada senão por ação regressiva do Estado, perante uma secção civil da Corte de Cassação. Com isso, desapareceu o processo de prise à partie para os juízes ordinários ${ }^{63}$ e se ampliou o campo da responsabilidade direta do Estado também pelas faltas pessoais dos juízes ${ }^{64}$

3.4. O artigo 121 da Constituição da Espanha de 1978 dispõe: "Os danos causados por erro judicial, assim como os que sejam conseqüência do funcionamento anormal da administração da justiça darão direito a uma indenização a cargo do Estado, conforme a lei". Esta veio a ser a Lei Orgânica do Poder Judicial (LOPJ), de $1^{\circ}$ de julho de 1985, que versa a matéria nos artigos 292-297. O sistema por ela implantado se caracteriza pela responsabilização direta e objetiva do Estado, reunidos os seguintes requisitos: a) um comportamento danoso, qualificável como erro judiciário ou como funcionamento anormal da administração da justiça, independente de culpa ou caso fortuito; b) dano injusto, isto é, o que o lesado não está obrigado a suportar; c) a relação de causalidade ${ }^{65}$. Inclui-se entre as hipóteses de reparação a prisão preventiva injusta. A lei tratou o erro e o funcionamento anormal como sendo coisas distintas, passando a doutrina a discutir tais conceitos. O erro poderia acontecer apenas na atividade própria do juiz, no exercício de sua função jurisdicional, e compreenderia o erro acidental e o culposo ${ }^{66}$. Nosete, porém, considera que o erro culposo ou doloso é modo de funcionamento anormal da justiça, e nessa classe deve ser incluído, reservando para a categoria "erro" apenas o acidental, pois este faz parte da essência do atuar judicial, cujo sistema está montado na presunção dessa falibilidade ${ }^{67}$. Limitado ao conceito de erro verificado em resolução judicial, Rebollo esclarece que tal resolução não é apenas a sentença firme, mas todo o tipo de atuação judicial, incluindo outra decisões, providências, sentenças. A não se atribuir essa amplitude ao conceito, o sistema retornaria ao erro judiciário reconhecido na revisão da sentença, o que seri reduzir demasiadamente a norma constitucional $^{68}$

Também há debate sobre se o funcionamento anormal seria (a) apenas o da administração da justiça na sua atividade jurisdicional stricto sensu, deslocadas para o sistema da responsabilidade da administração em geral as faltas cometidas pela administração da justiça em seu aspecto não jurisdicional ${ }^{69}$ ou (b) se estende não só para a atividade jurisdicional como para qualquer tipo de atuação exercida no complexo orgânico da administração da justiça, nela incluída participação de todos os seus auxiliares colaboradores $^{70} 71$.

Funcionamento anormal corresponde ao funcionamento defeituoso do direito francês, ocorrendo quando a justiça não funciona, funciona mal ou tardiamente, avaliad segundo standard de atuação e rendimento normalmente exigíveis ${ }^{72}$.

A indenização por prisão preventiva (art 294 da LOPJ) só é devida ao réu que venha a ser condenado pela inexistência do fato imputado. A regra tem sido criticada por excluir a absolvição por outro fundamento, como o de inexistência da autoria, o que talvez venha a justificar interpretação extensiva, para considerar que ela apenas fornece um exemplo.

\section{II - O sistema proposto}

1. Exame das objeções apresentadas

A importância e o interesse da disputa entre as correntes antagônicas sobre a res- ponsabilidade do Estado por atos de seus juízes, no Brasil, deve diminuir sensivel mente diante da nova realidade exposta no capítulo anterior, onde se viu que inúmeros ordenamentos jurídicos europeus admitem tal responsabilidade e passaram a regula mentá-la. É difícil conceber que, nesses países, com as alterações introduzidas na legislação, ficou abalada a soberania ou se perturbou a independência e a liberdade de seus juízes.

Contudo, retornando ao plano em que se encontrava o debate nacional, cabe examinar, embora sucintamente, essas questões.

1.1. A soberania é uma qualidade do Poder do Estado ${ }^{73}$, que se manifesta internamente como a capacidade de impor a vontade própria em última instância ${ }^{74} e$ externamente, na relação de igualdade com outros Estados. Ela é indispensável à manutenção da unidade do Estado, pois "a vida do Estado consiste numa perpétua reafirma ção da própria unidade ... Se o Estado não tivesse real supremacia sobre os indivíduos que o compõem, deixaria de ser Estado, pois a soberania está implícita em sua pró pria natureza"75. Necessária como fator de manutenção da união orgânica das forças que convivem no Estado, a própria soberania é una, não se repartindo entre os três poderes executivo, legislativo e judiciário não obstante seja através desses órgãos $e$ seus agentes que o Estado soberano exerce suas funções específicas. Se todos os poderes desempenham funções estatais, cuja fonte última reside na soberania, todos estariam igualmente acobertados pela mesma imunidade $^{76}$. Como os atos do Poder Executivo sujeitam o Estado, e os de Poder Legislativo também (pois até os defeitos danosos das leis inconstitucionais são indenizáveis) ${ }^{77}$, não há como argumentar com a soberania para excluir os atos judiciários. Na verdade, refletindo-se a soberania, com maior ou menor grau, em todos os atos específicos do Estado, não ficam eles excluídos do âmbito da responsabilização, pois a soberania "é um poder limitado pelo direito, e não só pelo direito positivo, do qual o Estado é uma das principais fontes de revelação, mas 
ainda pelo Direito em geral, pelo princípio superior de justiça e ainda pelo bem comum do grupo..."

1.2. A coisa julgada, assim como definida no Código de Processo Civil, corresponde à idéia de Liebman, para quem a eficácia natural da sentença se reforça quando precluem todos os recursos, sendo a coisa jul gada uma eficácia especial da sentença: "Art 467. Denomina-se coisa julgada material a eficácia que torna imutável e indiscutível a sentença, não mais sujeita a recurso ordiná rio ou extraordinário"19

O fundamento dessa autoridade está na lei, tendo o legislador optado entre duas alternativas: ou permitir a continuada renovação das lides, na busca incessante de uma sentença melhor, com a conseqüente insegurança para as relações sociais, ou atribuir sentença, com tal efícácia, a força de $l \mathrm{ei}^{80}$.

$\mathrm{Na}$ Constituição da República se incluiu entre os direitos fundamentais o respeito à coisa julgada: "Art. 5o, XXXVI. A lei não prejudicará o direito adquirido, o ato jurí dico perfeito e a coisa julgada". A regra, cujo destinatário imediato é o legislador com mais razão deve ser preservada pelo juiz, impedido de apreciar ação que reproduz outra já julgada ${ }^{81}$. Pontes de Miranda preocupou-se com o problema técnico da sentença contra legem e da sentença injusta, concluindo que, do ponto de vista jurídico, "a decisão contra legem é coberta pela coisa julgada formal e material. Mau e duro, mas assim tinha de ser para se cortar a antinomia 'incidência, aplicação injusta'... O que fica é o dever moral"82.

Portanto, dentro do nosso sistema cons titucional, é irrecusável ser a coisa julgada obstáculo ao surgimento de um direito de indenização contra o Estado enquanto subsistir a sentença trânsita em julgado. De um ponto de vista meramente processual poderse-ia dizer inexistente o impedimento, um vez que a ação indenizatória não contém os mesmos elementos da ação onde foi proferida a sentença causadora do dano injusto, sendo diferentes as partes, o pedido e a causa do pedir. É preciso reconhecer, porém, que o ordenamento jurídico não pode 26 conviver com a inconciliável oposição entre duas sentenças antagônicas e igualmente eficazes, como ocorreria, por exemplo, entre uma decisão criminal que mantém preso o réu condenado e uma outra sentença, que ordena ao Estado pagar uma indenização a esse mesmo réu, pelo fato da sua condenação. Pela natureza da coisa, e por uma exigência lógica, tal antagonismo deve ser evitado $^{83}$

O impedimento desaparece, porém, com o desfazimento da coisa julgada. Se o interessado intentar, no prazo decadencial de dois anos, ação rescisória do julgado cível (art. 485 do CPC), ou, em qualquer tempo, a revisão da sentença criminal (art. 622 do CPP), poderá obter, na mesma sentença de rescisão, ou em outra ação, a pretendida indenização.

A alegação da existência da coisa julgada não pode, pois, servir de motivo para a irresponsabilidade pelos atos jurisdicionais, porquanto a sentença com tal eficácia pode ser desfeita.

A precariedade de tal argumento ainda mais se evidencia quando consideramos que a coisa julgada é efeito de alguns atos praticados pelo juiz (sentenças definitivas, as que decidem a lide), ficando excluídas desse campo todas as sentenças que não produzem coisa julgada (as terminativas que encerram o processo, mas não decidem o mérito, as decisões interlocutórias, os despachos ordinários, as sentenças proferidas na jurisdição voluntária, as decisões preliminares nos processos cautelares, etc ${ }^{84}$.

1.3. A independência do magistrado e o espaço interno de liberdade para a decisão não justificam a pretendida isenção estatal. E absolutamente certo que a necessidade de interpretar a lei e de constantemente escolher entre diversas alternativas possíveis, cada uma delas determinante de sacrificios e perdas para uma das partes, são peculiaridades que fazem necessário configurar um sistema que preserve essa liberdade, a fim de que o julgador não seja atormentado, a cada vista dos autos, pela preocupação com os efeitos de uma possível ação ressarcitória contra o Estado ou contra ele mesmo. Por isso, cumpre estabelecer um sistema que elimine o risco de que "suas sentenças não reflitam os imperativos de sua consciência mas o cuidado por sua segurança" ${ }^{15}$. Isso se obtém garantindo-se-lhe, de um lado, a liberdade na escolha do conteúdo da decisão $e$, de outro, impondo-lhe a exigência d fundamentar todas as suas decisões de caráter jurisdicional ("Todos os julgamentos dos órgãos do Poder Judiciário serão públicos, e fundamentadas todas as decisões", Constituição, art. 93, IX), com o que se afasta, priori, a possibilidade do arbítrio, atribuindo-se ao julgador o dever de se manter nos limites do ordenamento jurídico vigente. Assim preservada ao juiz a liberdade de in terpretação da norma dentro do sistema, de se aceitar que, fora daí, como ocorre com o ato de qualquer outro poder, seja possíve a responsabilidade do Estado, estabelecendo-se saudável convivência entre os dois interesses coletivos: a responsabilidade do Es tado por atos danosos de seus agentes $\mathrm{e}$ independência do juiz ${ }^{86}$.

1.4. Anteriormente, discutiu-se longamente sobre a natureza do cargo exercido pelo magistrado e sua qualificação admini trativa, porque as Constituições anteriore atribuíam ao Estado a responsabilidade pelos atos dos seus "funcionários". Classifica do o juiz em categoria especial de servido público, desapareceria um dos requisito para a imputação. A Carta de 1988 superou o impasse ao mencionar os "agentes" das pessoas jurídicas de direito público, com preendendo todos aqueles que exercem legitimamente função estata ${ }^{87}$. O Judiciário presta um serviço público, isso é inegável, o juiz é o seu principal agente ${ }^{88}$. A existên cia de um estatuto próprio para a magistratura põe à mostra, apenas, a especialidade da categoria, dentro da estrutura estatal, mas não exclui o juiz do conceito amplo de agente do Poder Público.

\section{A interpretação das normas legais} vigentes

2.1. O artigo $37, \S 6^{\circ}$, da Constituição da República de 1988 enunciou o princípio da responsabilidade objetiva e direta do Estado por ato dos seus agentes. Exercendo o Poder Judiciário um serviço público e sendo o juiz o seu agente, seus atos caem no âmbito dessa regra geral.

Ocorre que o artigo 133 do CPC e o artigo 49 da LOMAN regulam os casos em que o juiz responde pessoalmente pelos da. nos, agindo com dolo, fraude ou desídia. $\mathrm{O}$ Código Civil, de sua vez, contém diversas disposições sobre a responsabilidade pessoal (artigos 294, 420, 421 e 1533).

2.2. Diante dessa aparente antinomia formaram-se correntes de opinião:

a) estão revogados pela Constituição os dispositivos das leis ordinárias que contrariam o princípio de que a responsabilidade é direta do Estado ${ }^{89}$

b) a responsabilidade é direta, tanto do Estado como do Juiz, nos casos previstos em lei, cabendo ao interessado escolher o sujeito passivo contra o qual pretende promover a sua ação indenizatória ${ }^{90}$

c) nos casos do artigo 133, I, do CPC, o Estado responde diretamente e tem ação regressiva contra o juiz; nas hipóteses do artigo 133, II, "trata-se de responsabilidade pessoal do juiz, com nítida feição correicional"1.

2.3. Para solver o impasse, é preciso considerar, em primeiro lugar, que tanto o Código de Processo Civil como a Lei Orgânica da Magistratura nada referem quanto à imediatidade da responsabilidade atribuída ao juiz, pelo que se deve interpretar tais regras em consonância com o texto constitucional, isto é, o Estado responde primária e diretamente frente ao lesado; o juiz respon. de regressivamente, frente ao Estado, no casos figurados no artigo 133, para a jurisdição civil, e no artigo 49 da LOMAN, para as demais jurisdições. Isso significa respeitar o princípio geral da responsabilidade direta do Estado pelos atos dos seus agentes, e a limitação do direito de regresso, em se tratando de ato judicial, às hipóteses dos artigos mencionados.

Já são diferentes as regras do Código Civil, editadas ao tempo em que predominava a doutrina regaliana e ainda à sombra 
de nossa longa tradição, mantida pelas Ordenações, de responsabilidade direta do juiz. Os preceitos da lei civil, não há como negar, batem de frente com o princípio d responsabilidade direta do Estado, pois expressamente assinam ao juiz a responsabilidade principal (art. 421), única (art. 1.552) ou subsidiária (arts. 294 e 420). Nessa parte, devem ser considerados revogados a partir da Constituição de 1946. Valem, porém, como referencial legal para a responsabilidade regressiva. $O$ mesmo ocorre com o art. 60 da Lei 4898/65: é inadmissível a sanção civil.

O artigo 5o, LXXV, da Constituição/1988, que é norma especial em relação à do artigo $37, \S 6^{\circ}$, pois explicitou o que já nesta se continha, serviu para realçar dois casos de responsabilidade estatal erigidos em direito fundamental do cidadão: por erro judiciário e por excesso de cumprimento de pena. O primeiro está sempre e necessariamente inserido no tema da responsabilidade por ato jurisdicional, dada a sua natureza, mas o segundo dependerá das circunstâncias, pois a demora na liberação poderá ser conseqüência de ato do juiz da execução da pena, de falta dos serviços cartorários da Justiça ou só de falha do serviço administrativo a que está afeto o sistem penitenciário, integrante da administração pública centralizada. A norma também serve para evidenciar a existência dos diverso planos onde tem origem a responsabilidade pelo exercício da função jurisdicional: a) a atividade jurisdicional propriamente dita exercida pelo juiz na sentença de mérito que transita em julgado; b) a atividade judicial pós-sentença ou pré-sentença; c) a atividade dos serviços da Justiça.

2.4. Em resumo, são constitucionais os artigos 133 do CPC e 49 da LOMAN, interpretados como hipótese de responsabilidade direta do Estado e onde se admite a ação regressiva contra o juiz; de outra banda, as disposições legais que atribuem responsabilidade direta ao juiz (principal ou subsidiária), como as contidas no Código Civil estão revogadas nesse ponto, pois que a res ponsabilidade direta é sempre do Estado, 28 servindo apenas para indicar, como as anteiores, a ação regressiva. $\mathrm{O}$ artigo 5o, LXXV, da Constituição explicita a regra geral do artigo $37, \S 6^{\circ}$, e traça parâmetros para a responsabilização pelo exercício da função jurisdicional.

\section{As características do sistema proposto}

3.1. Em primeiro lugar, cabe explicitar qual o âmbito do conceito de função jurisdicional.

Definir jurisdição tem sido um dos muitos pontos tormentosos do processo civil, para cuja solução concorreram as lições de Chiovenda (a jurisdição se caracteriza pela substituição da atividade privada pela do juiz) ${ }^{92}$, de Carnelutti (a jurisdição é a justa composição da lide) ${ }^{93}$, de Couture (jurisdição tem por objeto dirimir conflitos mediante decisões com autoridade de coisa jul$\operatorname{gada}^{94}$, de Galeno Lacerda (a jurisdição consiste no julgamento de questões controvertidas) ${ }^{95}$

Para o que nos interessa, em tema de responsabilidade civil do Estado, impende determinar se apenas o ato jurisdicional típico (independentemente do conteúdo ou da natureza que se lhe possa atribuir, conforme se adote uma ou outra das correntes doutrinárias existentes) integra o sistema próprio da responsabilidade do Estado por ato do juiz, ou se nele também se abrigam atos outros que não possam ser considerados atos jurisdicionais stricto sensu. Se a resposta fosse pela primeira alternativa, a exata apreciação do conceito seria de fundamental importância para a delimitação das fronteiras do instituto do qual tratamos; se prevalecer a segunda proposta, a questão diminui de importância.

A peculiaridade de tratamento que se dispensa ao tema, no campo da responsabilidade civil do Estado, deflui das condições próprias de trabalho do juiz: devendo fazer atuar o ordenamento jurídico, que necessita compreender e expressar através de um juízo de valor, depende ele de um espaço de liberdade interna que lhe garanta a possibilidade de escolher entre as diversas opções oferecidas; sendo terceiro em relação às partes, deve-se-lhe assegurar a independência $e$ a imparcialidade; posto a decidir sobre conflito de interesses, o ato judicial traz consigo a possibilidade de modificar posições jurídicas, acarretando vantagens e perdas à partes. Ora, esses predicamentos existem tanto no momento da sentença que julga lide e adquire a força de coisa julgada, quanto nos atos de administração do processo decisão de inúmeras questões de fato e de direito que devem ser superadas durante curso normal da demanda, tanto no processo de conhecimento, direcionado para típico ato jurisdicional, como no processo cautelar e no de execução ${ }^{96}$; tanto na jurisdição contenciosa quanto na jurisdição voluntária ${ }^{97}$, considerada esta como atividad administrativa e por isso mesmo tida pelo nosso Código "como estranha à verdadeir jurisdição, em sentido próprio" ${ }^{18}$. Contudo, e isso é o que nos basta, essa jurisdição voluntária é uma atividade administrativa distinta da massa dos atos administrativo em geral, à qual o Estado dispensou especia atenção, confiando-a aos juízes, pelas garan tias de que dispõem ${ }^{99}$.

Portanto, a função jurisdicional a que nos referimos, que acarreta a responsabilidade do Estado nos termos restritos aqui expostos, não se resume ao ato jurisdicional típico, ou ato jurisdicional stricto sensu, que a maioria da doutrina localiza na sentença de mérito, apta a ter a eficácia de coisa julgada, mas compreende a atividade exercida pelo juiz no processo, tanto antes como depois da sentença, tanto no processo de conhecimento, como no cautelar e no de execução, tanto na jurisdição contenciosa como na voluntária.

Além da atuação do juiz, compreende a atividade que o Estado necessariamente deve desenvolver no processo para dar cabo do seu dever de prestar a jurisdição, através do pessoal de cartório e auxiliares da Justiça. Fica restrita à atividade exclusivamente processual, porquanto o mais de sua atuação administrativa cai no âmbito do princípio geral da responsabilidade do Estado ${ }^{100}$.
3.2. Ainda como um esclarecimento preliminar, devemos enumerar, de acordo com o nosso ordenamento jurídico, as hipóteses de fato que podem dar causa ao dever de o Estado indenizar pelo exercício da função jurisdicional. Para isso consideramos as diversas especificações feitas na nossa legislação constitucional e ordinária (como a referência expressa feita ao erro judiciário) atendemos ao conceito amplo de função jurisdicional, assim como acima mencionado.

Servem de suporte à indenização: 1) a falta do juiz no exercício da função jurisdi. cional, de que é exemplo o disposto no artigo 133 do CPC; 2 ) o erro judiciário, que na maioria das vezes é uma espécie de falta do juiz, mas que também pode decorrer de simples acidente, além de ficar restrito à sentença de mérito (art. 5ㅇ, LXXV, primeira parte, da C.R); a falta do serviço, verificada no processo, de forma individualizada ou anônima (art. 5o, LXXV, segunda parte, da CR).

3.3. Estabelecida a premissa da responsabilidade do Estado pelos atos dos juízes, causadores de dano injusto, cumpre determinar as características do sistema em que ela ocorre.

O princípio da responsabilidade objetia, que se satisfaz com a causação do dano, não pode ser aceito no âmbito dos ato udiciais porque sempre, ou quase sempre da atuação do juiz na jurisdição contenciosa resultará alguma perda para uma das partes. Se esse dano fosse indenizável, transfe rir-se-ia para o Estado, na mais absolut socialização dos prejuízos, todos os efeitos das contendas entre os particulares. E por isso que a regra ampla do artigo $37, \S 6^{\circ}$ da Constituição, deve ser trazida para o limites indicados no seu artigo 5, LXXX, que admite a indenização quando $o$ ato $e$ falho (erro na sentença) ou quando falha 0 serviço (excesso de prisão). A partir daí, a legislação ordinária e complementar vale para delinear com mais precisão os contornos dessa responsabilidade. O Estado responde quando o juiz age com dolo, fraude (art. 133, I, do CPC; art. 49, I, da LOMAN), ou culpa grave, esta revelada pela negligên- 
cia manifesta (art. 133, II, do CPC; artigos 49 , II, e 56, I, da LOMAN) ou pela incapacitação para o trabalho (art. 56, III, da LOMAN) ${ }^{101}$

3.4. O dolo está aqui como elemento do ilícito absoluto, componente da conduta contrária ao dever genérico de não lesar. Age com dolo o juiz, no exercício de sua função, quando pratica ato que sabe indevido e assim o faz com o fim de violar a lei e causar direta ou indiretamente dano à parte. Nesse sentido, dolo é o pleno conhecimento do mal e o direto propósito de praticá-lo ${ }^{102}$. Mas não apenas o dolo direto como também o eventual: no dolo, "o agente tem a representação do resultado danoso, sendo o ato praticado com a intenção malévola de produzi-lo, ou apenas aceitado reflexamente esse efeito, ou ainda, tão só, correndo-se o risco de que se produza" ${ }^{103}$.

Além da hipótese de a própria conduta do juiz ser suficiente para produzir o resultado danoso, através da sentença ou de outro ato no processo, ainda pode acontecer, se bem que com menor freqüência, a espécie de dolo consistente em induzir maliciosamente outrem à prática do ato que o prejudica, v.g., na mediação de um litígio, induzindo maliciosamente a parte a celebrar acordo ruinoso. E o dolo de que trata o art. 92 do Código Civil: "Os atos jurídicos são anuláveis por dolo, quando este for a sua causa", que se conceitua como sendo o "artifício ou expediente astucioso empregado para induzir alguém à prática de um ato que o prejudica, e aproveita ao autor do dolo ou a terceiro"104. Na omissão dolosa deve estar presente, mutatis mutandis, o mesmo elemento subjetivo da inexecução dolosa dos contratos ${ }^{105}$ : a voluntária e consciente transgressão do dever, com a intenção de causar o dano à parte, excluída a simples determinação voluntária de descumprir.

A fraude, a rigor, está incluída no conceito amplo de dolo, que compreende toda a forma de artifício capaz de induzir outrem a engano ${ }^{106}$. O destaque dado pelo legislador do Código de Processo Civil (art. 133, I) deve ser interpretado como preocupação de fazer menção às outras manobras 30 enganosas que o agente pode praticar para falsear a realidade e prejudicar umas das partes, especialmente pela falsificação ideológica ou material, pela reprodução incompleta de documentos, etc.

A culpa que enseja a responsabilidade estatal por ato do juiz se manifesta em três modalidades: a) na recusa, omissão ou retardo da providência que deva ordenar (art. 133, II, CPC); b) na negligência manifesta (art. 56, I, da LOMAN); c) na insuficiente capacitação para o desempenho da função (art. 56, III, da LOMAN). A hipótese da alínea $a$ se concretiza com o injustificado desatendimento do pedido da parte, dez dias depois de apresentado seu requerimento através do escrivão (art. 133, parágrafo único). É uma espécie de omissão, mas circunscrita à ausência de ordem judicial para uma certa providência. Isto é, falta a ordem, como a de expedição de alvará, de mandado de soltura, etc. Já na alínea $b$ acima, a "manifesta negligência" abrange qualquer outra omissão do juiz dentro do processo, desde a falta de despacho, ausência de solenidades aprazadas, até a demora na prolação da sentença ${ }^{107}$.

A incapacidade para o desempenho do trabalho judicial é uma espécie de imperícia que se manifesta na ignorância ou no erro sobre técnica profissional necessária ao exercício da função.

Em todos os casos, a culpa deve ser grave, isto é, expressar inescusável desatenção ao cumprimento do dever funcional. A falta de justificativa para a recusa, omissão ou retardo da ordem de providência deve significar grave desconsideração para com o interesse da parte, que as circunstâncias de nenhum modo autorizavam. A negligência deve ser manifesta, evidente a qualquer exame, reveladora de descuido grosseiro ao dever de cuidado no exercício das funções. A demora é a intolerável procrastinação dos atos de ofício, não justificada pelos fatos. A incapacidade é a inaptidão revelada através do desconhecimento de regra elementar ou do erro crasso.

Estas últimas situações (letras "b" e "c") impondo ao Estado o dever de retirar seu autores do serviço ativo (art. 56 da Loman), têm como corolário responsabilizar o mesmo Estado pelos danos que seus juízes, nessa qualidade, causaram às partes ${ }^{108}$. O procedimento administrativo contra o juiz, porém, não é pressuposto para a responsabilização patrimonial do Estado, mesmo porque a hipótese pode ser isolada, bastante grave para justificar a reparação do dano, mas insuficiente para a penalização administrativa.

3.5. O erro judiciário ocorre por equivocada apreciação dos fatos ou do direito aplicável, o que leva o juiz o proferir sentença passível de revisão ou de rescisão. Pode decorrer de dolo ou culpa do juiz, de falha do serviço ou, até mesmo, "se produzir fora de qualquer falta do serviço público. E um risco inerente ao funcionamento do serviço da justiça. Apesar da diligência e da extrema atenção dos magistrados e de seus auxiliares, os erros judiciários podem surgir... ${ }^{109}$. $O$ erro pode estar em sentença proferida em qualquer jurisdição ou instância, a despeito de estar comumente associado à sentença criminal ${ }^{110}$. Como adverte Ardant, quaisquer que sejam as diferenças entre a justiça civil e a justiça criminal, a responsabilidade deve englobar o erro de ambas, pois o risco do erro é inerente à função jurisdicional, seja cível ou criminal ${ }^{111}$.

Além do erro judiciário, reparável após o desfazimento da sentença ${ }^{112}$, devemos incluir no âmbito da reparação civil a prisão preventiva, quando ilegal, e a legal de quem veio a ser finalmente absolvido ${ }^{113}$ com fundamento na categórica negativa da existência do fato ou da autoria, ou pelo reconhecimento da licitude do comportamento. Os autores discutem sobre a incidência, também, da absolvição por falta de provas ${ }^{114}$, o que parece incabível. A falta de provas de qualquer dos pressupostos da condenação criminal inibe a formulação do juízo condenatório, mas não tem reflexos na jurisdição civil, nem pode fazer surgir para o réu uma pretensão à indenização fundada em ofensa a direito sobre o qual se tem dúvida.

3.6. Tratemos agora dos casos que, não derivando diretamente da ação. do juiz, como os acima referidos, caracterizam hipóteses de mau funcionamento ou funcionamento anormal do serviço judiciário, que não funciona, funciona mal ou funciona tardiamente, ocorrentes desde a propositura da ação até os atos executórios da sentença final ${ }^{115}$

O monopólio da prestação da justiça trouxe para o Estado, conseqüentemente, o dever de cumprir o encargo a contento, de modo a não violar o direito que prometeu proteger. Os efeitos daninhos da má organização dos serviços judiciários, resultado da incompetência e da visão acanhada da dministração pública, não podem recair sobre os ombros dos cidadãos. Sequer a vasta diferença entre o que existe e o que seria razoável esperar, nas condições do país, pode servir de escudo à incúria, à inoperância e à incapacidade de ordenar o sistema udiciário de modo a atender à demanda. $\mathrm{O}$ Estado deve ser capaz de resolver satisfatoriamente o problema da justiça, com os recursos de que dispõe, o que é plenamente possível, ainda quando escassos, desde que se comece por admitir que o nosso. sistema processual é inviável, como evidenciam as pilhas de milhares de autos nos tribunais e nos cartórios, angustiando juízes, advogados e partes. É preciso criar mecanismos geis, céleres e baratos, adaptados aos recuros econômicos da comunidade que os sustentam. Para isso talvez seja imperioso contar com menos palácios e mais cartórios, menos carimbos e mais resultados, menos recursos e mais simplicidade ${ }^{116}$

O mau funcionamento da justiça pode resultar da culpa de seu agente, determinado e individualizado, ou da culpa anônima simples falta do serviço. $O$ acúmulo do trabalho, cujo ingresso não pode ser controlado, a insuperável falta de juízes e servidores, em virtude da morosidade própria da burocracia, que é lenta desde o processo de seleção do pessoal, e a falta de recursos suficientes são fatores determinantes do funcionamento anormal, sem que se possa precisar aquele a quem se deve imputar a falta. Para o lesado, basta demonstrar a falha do serviço, o dano e o nexo causal ${ }^{117}$ 
O mau funcionamento corresponde à hipótese mais genérica de denegação da justiça e caracteriza, normalmente, uma ilegalidade $^{118}$ pode ocorrer em qualquer plano, por ação do agente no desempenho de função processual, do que serve de exemplo o excessivo cumprimento da pena (art. 50, LXXX da Constituição).

3.7. A ação de reparação de danos pressupõe o esgotamento dos recursos ordinários, pois este é o caminho proposto pela própria lei para a retificação das irregularidades e equívocos que previsivelmente podem ocorrer durante o processado. Se a parte se contenta com o ato e se omite na reclamação, concorre para a sua permanência e não tem do que se queixar. Em certos casos, contudo, devemos atentar para a dificuldade do exercício da defesa e para precariedade dos meios de que dispõe o interessado para fazer valer o seu direito, como muitas vezes acontece com a assistência judiciária gratuita, que o Estado ainda não conseguiu organizar com suficiência. Sendo dele o dever de prestar a assistência, a eventual deficiência da defesa não pode ser causa de exoneração.

Havendo sentença com trânsito em julgado, é pressuposto do pedido indenizatório o prévio desfazimento daquele ato, a ser obtido através da rescisão, no juízo cível nos casos do artigo 485 do CPC, e de revisão no juízo criminal (art. 621 do $C P C$ ). No crime, a lei autoriza ao juiz da revisão deliberação sobre a verba indenizatória; no cível, nada impede a cumulação de pedidos.

3.8. São causas exonerativas da responsabilidade do Estado:

a) quando o dano decorre com exclusividade da ação dolosa ou culposa da parte (deixando de fazer prova, prestando esclarecimentos inexatos, omitindo-se nos atos a que deve comparecer, conluiando-se com outra parte, induzindo testemunhas, retendo ou extraviando autos, deixando de praticar atos de seu dever, corrompendo os que participam da cena judiciária, etc.). Se há concorrência de culpas, a responsabilidade do Estado será atenuada na proporção de sua participação causal;

32 b) decorrer o dano de má interpretação dada pelo juiz à lei ${ }^{119}$. Os conceitos indeterminados ("mulher honesta", "motivo relevante", "interesse público", etc.) e as cláusulas gerais (nestas devendo o juiz estabelecer previamente qual a norma de conduta que deveria ter sido observada para o caso, como no art. 159 do Código Civil), deixam ao juiz largo espectro decisório, cuja opção deve ser admitida enquanto não arbitrária, isto é, enquanto fundamentada dentro do sistema jurídico vigente ${ }^{120}$;

c) resultar o dano de força maior, pois é uma causa estranha ao serviço, ordinariamente imprevisível em sua produção e sempre absolutamente irresistível ${ }^{121}$. O caso fortuito, por ser um evento interno, diretamente conectado com o funcionamento do serviço mas com causa desconhecida, não isenta de responder o Estado pelo mau funcionamento do serviço. Enquanto na força maior a causa do dano é externa, inexistindo nexo de causalidade entre a ação do juiz ou do serviço e o resultado, no caso fortuito a causa é a falta do serviço, ainda que desconhecida;

d) ter sido o dano produzido por terceiro, cujo resultado não incumbia ao Estado evitar, nas circunstâncias do fato:

e) o estado de necessidade defensivo, quando o perigo foi criado pelo lesado, que assim sofre o dano resultante da ação necessária do Estado para afastar o perigo. Nos demais casos não há exclusão: "O estado de necessidade pré-exclui a ilicitude, não a responsabilidade"122.

3.9. O Estado tem o direito de propor a ação regressiva contra o juiz causador do dano desde que este tenha agido com dolo, fraude (art. 133, I, do CPC), ou culpa grave, por negligência manifesta (art. 133, II, do CPC, e 56, I, da LOMAN) ou inaptidão (art. 56, III, da LOMAN), e nos casos previstos no Código Civil, já mencionados, desde que haja culpa.

Réu na ação de indenização promovida pelo lesado, pode o Estado denunciar a lide ao juiz, a fim de obter nesse mesmo processo sentença sobre o seu direito de regresso (art. 70, III do CPC). $\mathrm{Na}$ jurisprudência predominante, tem sido recusado ao Estado o direito de denunciar a lide ao servidor culpado, sob o argumento de que se estaria embutindo, em ação onde se discute a responsabilidade objetiva, o tema subjetivo da culpa, matéria estranha à relação jurídica sobre que versa a ação ${ }^{123}$.

3.10. A competência para o processo e julgamento de demanda contra o Estado, em sendo caso de erro judiciário, é do tribunal competente para a ação de revisão ou de rescisão; nos casos em que se deva apurar dolo, fraude ou culpa grave do juiz, definidas no estatuto disciplinar, no mesmo tribunal competente para aplicar a sanção administrativa; nas demais hipóteses de falta do serviço, no juízo onde podem ser intentadas as ações contra a Fazenda Pública.

\section{Conclusạ̃o}

1. É sempre direta do Estado a responsabilidade pelos danos decorrentes do exercício da função jurisdicional.

2. Essa responsabilidade tem causa na ação do juiz que age com dolo, fraude ou culpa grave (negligência manifesta ou incapacidade para a função), no erro judiciário e nos demais casos de mau funcionamento dos serviços da Justiça, incluindo a falta anônima.

3. São inaceitáveis as teses que justificam a irresponsabilidade pelo exercício da soberania, respeito à coisa julgada ou necessida de de preservação da independência do juiz.

4. A independência do juiz se preserva vedando a responsabilização por interpretação do direito ou dos fatos, de acordo com o sistema.

5. Por exercício da funçãa jurisdicional se entende a prática do ato jurisdicional em sentido estrito (sentença) e dos demais ato judiciais praticados durante o processo, na jurisdição contenciosa ou voluntária

6. A ação de indenização por ato jurisdicional em sentido amplo somente pode ser intentada após esgotados os recursos ordinários ou afastada a coisa julgada cível ou criminal.
7. O direito de regresso contra o juiz somente ocorre havendo dolo, fraude ou culpa grave, nos casos definidos na lei.

\section{Notas}

1 Pimenta Bueno, Direito Público Brasileiro e análise da Constituição do Império, Rio: Ministério da Justiça, 1958, p. 428

${ }^{2}$ Artigo 86, § 20. "A sentença de reabilitação reconhecerá o direito do reabilitado a uma justa indenização, que será liquidada em execução, por todos os prejuízo sofridos com a condenação. A Nação, ou o Estado, são responsáveis pela indenização

3 O Dec. 1939, de 28.8.1908, estendeu o processo instituído pela Lei 221/1894 à indenização por danos causados por autoridades administrativas dos Estados e Municípios.

${ }^{4}$ Ac. do STF, de 28.4.1897: A Fazenda não responde pelas faltas dos funcionários. O Direito, v. 73, p. 504 "Le Code civil brésilien a suivi la théorie de la faute que vient du droit roman, selon la systematisation que commence avec les Glossateurs" (Clóvis do Couto Silva, Principes Fondamentaux de la responsabilité civile en Droit brésilien et comparé, Porto Alegre, Liçōes Universidade de Paris XII, datilografado, 1988, p. 82.

${ }^{6}$ Hely Lopes Meirelles, Direito Administrativo Brasileiro, São Paulo: Editora Revista dos Tribunais, 1989, p. 552.

7 No texto, o emprego da expressão "responsabilidade direta" quer significar a possibilidade de o lesado agir diretamente contra o Estado, de forma primária e imediata.

${ }^{8} \mathrm{Na}$ tramitação do projeto, foi rejeitada a emenda que restringia a responsabilidade apenas aos atos de gestão. 9 Rui Barbosa, Obras Completas, v. XXV, t. V, p. 178, parecer de 14.3.1898; Revista dos Tribunais, v. 133, p 438, parecer de 18.5.1900.

${ }^{10}$ Pedro Lessa, Do Poder Judiciário, Rio: Livraria Francisco Alves, 1915, p. 161.

${ }^{11}$ Amaro Cavalcanti, Responsabilidade Civil do Estado, Rio: Borsoi, ed. 1957, v. II, p. 653

12 Ac. do STF de 28.4.1887, em O Direito, v. 73, p. 504

13 Ac. do STF de 27.7.1898, em O Direito, v. 77, p. 487.

${ }^{14}$ Rev. de Direito, v. 65 , p. 320 ; v. 78 , p. 526 ; v. 81 p. 343

15 Alcino de Paula Salazar, Responsabilidade do poder público por atos judiciais, Rio: Canton \& Reile, 1941, p. 27 e seguintes.

${ }^{16} \mathrm{O}$ dissídio que lavrou na doutrina sobre a prevalência da teoria do risco integral ou do risco administra- 
tivo (exposta no texto) não tem maior relevância, pois os defensores de ambas as correntes aceitam a possibilidade de exclusão ou atenuação da responsabilidade do Estado sempre que provada a atuação de fatores causais estranhos ao Estado, como a culpa exclusiva ou concorrente da vítima (Alcino Pinto Falcão, Responsabilidade patrimonial das pessoas juridicas de Direito Público, na RDA, 11/45; Yussef Said Cahali, Responsabilidade Civil do Estado, São Paulo: Ed. Revista dos Tribunais, 1982, p. 30 e seguintes; Edmir Netto de Araujo, Responsabilidade do Estado por ato jurisdicional, São Paulo: Ed. Revista dos Tribunais, 1981, p. 42). Apenas corrente minoritória apregoa que o Estado responde sempre, ainda quando a vítima seja culpada pelo evento O STF tem reiteradamente acolhido pelo evento. O STF tem reiteradamente acolhido a teoria do risco administrativo: Ac. de 24.2.1987, no Al - JSTF, 103/25. No mesmo sentido: RT] 55/50. Ver: Hely Lopes Meilles, Dirito Administativo Hely Lopes Meirelles, Direito Administrativo Brasileiro, 1989, p. 549 e seguintes; Carlos Mário da Silva Velloso, Responsabilidade Civil do Estado,
Informação Legislativa, 1987, $\mathrm{n}^{\circ}$ 96, p. 233.

17 Para apuração da culpa do Estado como garantidor do bem e obrigado a impedir o resultado, aplicam-se as regras estabelecidas para apuração da "faute de service", para o que nos ajuda a liçăo de Rivero: a culpa do serviço e uma deficiência real do serviço, que surge quando ele fica abaixo do seu nível médio; não é imputável aos agentes, pelo que não há razão para distinguir entre culpa de um agente individualizado ou culpa anônima; não há norma abstrata para caracterizar a culpa, que deve ser apreciada em cada caso; relativamente independente da legalidade, pois pode haver ato ilegal apenas quanto às suas formalidades externas, que nas circunstâncias pode não se constituir em fato danoso; a culpa admite graus; o juiz pode considerar que certos serviços, particularmente dificeis só respondem por culpa grave, como os serviços de proteção do fogo; a prova da culpa incumbe á vítima mas é possível presumir-se a culpa (Jean Rivero, Tratado de Direito Administrativo, Coimbra: Almedina, 1981, p. 319-320).

18 "A responsabilidade objetiva da pessoa jurídica de direito público, prevista na Constituição Federal, não significa seja o Estado responsável, sempre, por dano causado a terceiro por seus órgãos presentativos. Não se adotou, no sistema jurídico brasileiro, em tema de responsabilidade civil, a teoria do risco integral. Se o ato juridico ilícito do policial fora praticado em legí tima defesa, não pertencem ao Estado o dever e a obrigação de indenizar a vitima". Ac. da $1 \stackrel{a}{a}$ Turma do STF, de 15.9.1981, na LEX, JSTF, 36/49.

${ }^{19}$ RTJ 78/243.

20 Themistocles Cavalcanti, Tratado de Direito Administrativo, p. 417.

21 "Nestas hipóteses (enchentes, vendavais) a indenização pela Fazenda Pública só é devida se se comprovar a culpa da administração". Hely Lopes Meirelles, Direito Administrativo Brasileiro, p. 555

34
22 Celso Antonio Bandeira de Mello, Responsabilidade patrimonial da administração por atos administrativos, RDA 132/48.

${ }^{23}$ B. Starck, Essai d'une théorie générale de la responsabilité civile considérée en sa double fonction de garantie et de peine privé. Paris: Rodstein, 1947. Foi com Starck que se iniciou a orientação de se considerar a responsabilidade civil do ponto de vista da vítima: "Nós tentamos uma construção inteiramente nova, com o único cuidado de fornecer uma explicação lógica e simples aos dados reais do problema. A existência de diversos casos de responsabilidade independente de toda imprudência, negligência ou dolo, no entanto indenizáveis, com a idéia do risco não podendo justificar de uma forma satisfatória, nós nos perguntamos se o problema do fundamento da responsabilidade civil não tinha sido mal colocado diante do dilema: culpa ou risco. Pareceu-nos que estas duas teorias, para alguns irredutivelmente opostas, se encontravam num defeito comum. Elas procuravam a razào, a justificação da obrigação de reparar o prejuízo causado, se colocando unicamente do ponto de vista do autor do dano; elas são, como se tem sublinhado, todas as duas subjetivas. Não será esta a razão principal de seu malogro? Não se poderia, invertendo o curso habitual do pensamento jurídico, abordar o problema da responsabilidade civil do ponto de vista da vitima 2 " (p. 10). "A razão, a causa jurídica de toda a responsabilidade civil nazo, a causa juridica de toda a responabilidade civil cando do ponto de vista da vitima" (p. 259). Essa cando po plo mire a vima de listaspe: La responsabilidad que mira a la victima es, a nuestro juicio, la verdaderamenCivil Ba ( 30) . Bues Aires: Editorial Hammurabi, 1992, p. 30). Na Argentina, tal perspectiva assumiu importancia fue de $180^{\circ}$. fue de 180 , se comenzo a estudiar el fenomeno desde el dañado y del daño y no exclusivamente desde el dañador" (Carlos A. Ghersi, Responsabilidade Civil, cit., p. 46)

24 Não distinguimos, para o estudo do tema, entre indenização por fato lícito e ressarcimento por fato lícito, como tem sido proposto na doutrina estrangeira. 25 A orientação jurisprudencial predominante é contrária à denunciação da lide ao servidor, sob o fundamento de que insere matéria relacionada com a culpa em açáo indenizatoria onde a responsabilidade do Estado é objetiva. Ocorre que a denunciação da lide sempre traz para a demanda já existente uma nova relação, cuja natureza e conteúdo é necessariamente diversa da estabelecida entre autor e réu. Vedar a denunciação apenas por esse motivo seria negar o próprio instituto da denunciação da lide.

${ }^{26}$ Yussef Said Cahali, Responsabilidade Civil do Estado, p. 17/19; Jorge Mosset Iturraspe, Responsabilidade Civil, p. 37/39.

${ }^{27}$ Clovis V. do Couto e Silva, Le droit civil brésilien - Aperçu historique et perspectives d'avenir (Liçōes na
Universidade de Florença), Porto Alegre, datilografado, 1986, p. 5.

28 J. Isidoro Martins Jr., História do Direito Nacional, Rio: Empresa Democrática Editora, 1895, p. 93.

29 José Almagro Nosete, Responsabilidad judicial, Córdoba: Ed. El Almendro, 1984, p. 15

30 Lenine Nequete, $O$ poder judiciário no Brasil Crônica dos tempos coloniais, Porto Alegre: Ed. Ajuris, v. II, p. 296 e seguintes.

31 Dec. 737, de 25.11.1850: "Art. 677. As nulidades argüidas não sendo supridas, ou pronunciadas pelo Juiz importarão: $\S 1 \%$. A anulação do processo na parte Juiz importarăo: $\$ 1$. A anulação do processo na parte argüiu; $§ 2^{\circ}$. A responsabilidade do Juiz".

32 Pedro Lessa, Do Poder Judiciário, p. 165.

33 Art. 294. "Ficará subsidiariamente responsável o juiz que conceder a alienação fora dos casos e sem as formalidades do artigo antecedente, ou não providenciar na subrogação do preço em conformidade com o parágrafo único do mesmo artigo."; Art: 420 . "O juiz responde subsidiariamente pelos prejuízos que sofra menor em caso de insolvência do tutor, de lhe não ter exigido a garantia legal ou de O não haver removido, tanto que se tornou suspeito."; Art. 421 "A responsabilidade será pessoal e direta, quando o Juiz não tiver nomeado tutor, ou quando a nomeacão não houver sido oportuna."; Art. 1.551. "Consideram-se ofensivos da liberdade pessoal (art 1.550): I - cáse ofensivos II - a prisão por queixa ou denúncia falsa e privado; III - a prisão ilegal (art. 1.552)""; Art. 1.552 "No caso do artigo antecedente, ${ }^{\circ}$ HI " Át a 1.552 . "No caso do artigo antecedente, no 111 , só a autoridade, que

${ }^{34}$ Artigo 630 do Código de Processo Penal: "O Tribunal, se o interessado o requerer, poderá reconhecer o direito a uma justa indenização pelos prejuizos sofridos. $§ 1^{\circ}$. Por essa indenização, que será liquidada no juizo civel, responderá a Uniá, se a condenaçáo tiver sido proferida pela Justiça do Distrito Federal ou de Território, ou o Estado, se o tiver sido pela respectiva justiça. $\S 2^{\circ}$. A indenização não será devida: a) se o erro ou a injustiça da condenaçấo proceder de ato ou falta imputavel ao proprio impetrante, como a confissão ou a ocultação de prova em seu poder; b) se a acusação houver sido meramente privada". (A ressalva da letra "b" é inadmissivel).

$35 \mathrm{O}$ recente projeto do Estatuto da Magistratura $\mathrm{Na}$ cional, encaminhado pelo STF ao Congresso Nacional (Diário da Justiça de 21.12.1992), nada referiu sobre a responsabilidade por ato judicial. Esta seria a sede legislativa mais adequada para regular a matéria em nivel nacional e para todas as jurisdiçōes.

${ }^{36}$ Lei Complementar no 35, de 14.3.79 (Lei Orgânica da Magistratura Nacional - LOMAN): Art. 56. "O Conselho Nacional da Magistratura poderá determinar a aposentadoria, com vencimentos proporcionais ao tempo de serviço, do magistrado: I - manifestamente negligente no cumprimento dos deveres do cargo; II
de procedimento incompativel com a dignidade, honra e o decoro de suas funçōes; III - de escassa ou insuficiente capacidade de trabalho, ou cujo proceder funcional seja incompativel com o bom desempenho das atividades do Poder Judiciário".

37 Philippe Ardant, o hoje Reitor da Universidade de Paris, em sua excelente monografia, enumerou os fundamentos teóricos contrários ao princípio da responchich partes näo colaborm para o funciono dos julzes, as pa Juscya há o risco de coluro ente as porreto

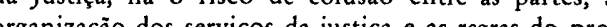
organizaçáo dos serviços da justiça e as regras do procesuro of ra com garancias sufcientes para inpedir a causaçào de algum dano, o recurso a justiça é um ato voluntario; o reconhecime ra responsabilidade acarretaria uma carga muito grande para as finanças públicas, a funçăo jurisdicional, como manifestação da soberania, é irresponsável, a autoridade da coisa julga da impede a responsabilizaçăo por dano resultante da fonction juridictionelle, Paris: LGDJ, 1956, p. 171 186).

${ }^{38}$ Ac. do STF de 13.10.1971, na RTJ 64/689.

39 Ac. do STF de 25.3.1980, na RTJ 94/423.

40 É apenas a reiteração de precedentes consolidados desde o início do século: "Não é a União civilmente responsável pelas decisoos contenciosas ou administrativas, proferidas pelo Poder Judiciário, porque este não representante ou preposto dela, mas um dos orgão da soberania nacional" (Ac. do STF de 29.10.1926, $\mathrm{n}$ Revista Forense 49/46).

41 Pedro Lessa, Do Poder Judiciário, p. 164

Carlos Maximiliano, Comentários à Constituição Brasileira (1946), Rio: Freitas Bastos, 1954, v. III, p.

${ }^{43}$ Ac. do STF de 9.12.1958, na Rev. For. 194/159. Na

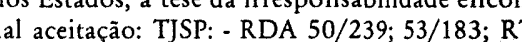
259/127; TJRS: - Ajuris 19/114; Rev. de Jur. TJRS $113 / 367$

${ }^{44}$ Os julgados de procedência de ações indenizatórias constituem exceção, destacando-se o acórdão do antigo Tribunal Federal de Recursos, de 23.7.1957, que condenou o Estado a indenizar suplente de deputado indevidamente af astado do exercício do mandato por sentença judicial (RDA 54/188). Nesse ponto, é indeclinável a referência Baleeiro, que nà o he historico voto do Min. Aliomar Baleeiro, que nào chegou a convencer a maioria do 121 , de 13.10.1971, b ela pela responsabilidade direta do Estado em razão da desidia do juiz, que conservou displicentemente consige, por mais de dois anos, os autos de um processo de
réu (RTJ 64/689). 45 Além de Carlos Maximiliano e Pedro Lessa, já citados, ver: Carvalho Santos, Código Civil Brasileiro In erpretado, v. 1, p. 356; Castro Nunes, Da Fazenda ública em Juizo, 420/44; Pedro Batista Martins, Comentários ao CPC, I/361: "Tornar o juiz civilmente 
responsável pelos julgamentos que profere é absurdo que a doutrina jamais pôde tolerar. Nem o juiz, nem o Estado que o houver investido na função, respondem pelos danos ..."; Hely Lopes Meirelles, um dos mais Administrativo Brasileiro", p. 557, afirma: "O ato jud cial típico, que é a sentença, nào enseja responsabilidade civil da Fazenda Pública, salvo na hipótese única do art. 630 do Código de Processo Penal, uma vez obtid a revisão criminal. Nos demais casos, as decisões judiciais, como atos de soberania interna do Estado, propiciam qualquer ressarcimento".

${ }^{46}$ Alcino de Paula Salazar, Responsabilidade do Poder Público por Atos Judiciais, p. 95 a 99.

47 José de Aguiar Dias, Da responsabilidade civil, Rio Forense, 1979, v. II, p. 320 e seguintes, no 214 .

48,49 Juary C. Silva, Responsabilidade civil do Estado por atos jurisdicionais, Revista dos Tribunais, 1965, 351/19; Cretella Júnior, Responsabilidade do Estado por atos judiciais, Revista de Direito Administrativo, 197, $99 / 1$; Joào Sento Se, Responsabilidade civil do Estado por atos judiciais, São Paulo: Editora José Bushatsky Ltda., 1976; Nelson Luiz Guedes Ferreira Pinto, A responsabilidade civil do Estado por atos judiciais, Cadernos de Pos-Graduação da Universidade Federa de Minas Gerais - Faculdade de Direito, 1977, p. 143; Edmir Neto de Arú por ato jurisdicional, Sao Paulo: Editora Revista dos Coletim de Dirrito Administrativo jan 1986, de, Boletim de Direito Administrativo, jan. 1986, 20, Mário Moacyr Porto, Responsabilidade do Estado 563/9; Ada Pellori

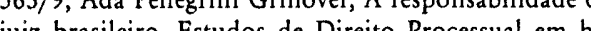
juiz brasilero, Estudos de Direilo Processual em homenagem a Jose Frederico Marques, Editora Saraiv do , p. 3; Volnei Ivo Carlin, A responsabilidade civil do Estado resultante do exercicio das funçoes juris cionais, Revista dos Tribunais, 1982, 557/15, lussef Said Cahall, Responsabilidade civil do Estado, Sa Paulo: Editora Revista dos Tribunais, 1982, Jose Augusto Delgado, Responsabilidade civil do Estado pela de mora na prestaçăo jurisdicional, Revista de Processo $1985,40 / 147$; - Poderes, de8 301/335; Calos Maso da Juiz, Revista Forense, 1988, 301/335, Carlos Mário Silva Velloso, Responsabilidade civil do Estado, Revis ta de Informação Legislativa, 1987, 96/233; ;, Problemas e soluçoes na prestaçào da justiça, Revista do Tribunals, 1991, 664/215; Luiz Rodrigues Wambier, A responsabilidade civil do Estado decorrente dos ato jurisdicionais, Revista dos Tribunais, 1988, 633/3 Adauto Suannes, A responsabilidade do juiz pelo erro judiciário, Cadernos de Advocacia Criminal, dez. 1988 v. 1, n. 6, p. 124; -, Má prestação judicial e indenização correspondente, Revista Brasileira de Ciências Crim nais, Revista dos Tribunais, $n^{\circ}$ especial de lançamento, p. 62; Maria Emilia Mendes Alcantara, Responsabilidade do Estado por atos legislativos e jurisdicionais, $S$ Paulo: Editora Revista dos Tribunais, 1988; José Guilherme de Souza, A responsabilidade civil do Estado pelo exercicio da atividade judiciária, Revista dos tr36 bunais, 1990, 652/29; Artur Marques da Silva Filho, 67izes irresponsaveis, Revista dos Tribunais, 1991, 674/70; Alberto Bittencourt Cotrim Neto, Da responsabilidade do Estado por atos de juiz em face da Constituição de 1988, Ajuris, 1992, 55/76.

Nicolò Trocker, La responsabilità del giudice. RTDPC, 1982, p. 1283 .

${ }^{51}$ Adelaide N. Figurelli, La responsabilità disciplinare del giudice: il dibattito più recente e la prospettiva de soluzioni nuove, RTDPC, 1982, p. 260.

52 Nicola Picardi, Problemi attuali dela responsabilità del giudice, RTDPC, 1979 , n 4, p. 1485 .

53 "The Supreme Court may, by statute, lack jurisdiction to deal with a particular matter ... but it has jurisdiction to decide whether or not it has jurisdiction Jur (1812), "in" Such matts. . Caso Taffe li. Donn" (1812), "in" Giova Mirros v MPO reso 1975, no 3,1060 . 7. $\mathrm{n}$ 3, p. 1060. Tambe per Denis Levy, La responAngleterre, Paris: LDGJ, 1957, p. 103.

44 Sirros era um cidadão turco contra o qual, em 1971 foi expedida, por um "magistrate" (Juiz de Paz), ordem de expulsão da Inglaterra. Sirros recorreu à Crown Court, que rejeitou o apelo. Depois de findo o julg mento e proclamado o resultado, quando Sirros se retirava da sala, o juiz ordenou a sua prisão, executada quando o demandante ja se encontrava na rua. Sirros propós a ação de habeas corpus, que veio a ser julgada procedente, porque ele fora preso por ordem expedida depois do caso estar concluido. Sirros promoveu, enão, açào de indenização contra o Juiz que ordenara sua prisão e contra o oficial que a cumprira. A ação foi julgada improcedente, mas o fundamento da decsão contrariava a orientação jurisprudencial adotada há séculos.

55 Walker \& Walker, The English Legal System, London: Buther Worths, 1980, p. 220/221.

${ }^{56}$ Giovani Criscuolo, I nuovi limiti ..., p. 1064

57 Walker \& Walker, The English Legal System, p. 221 transcrevendo o voto de Lord Denning: "He should not have to turn the pages of his book with trembling fingers, asking himself: "If I do this, shall I be liable in damages"? So long as he does his work in the honest belief that is within his jurisdiction, then he is not liable to an action. He may be mistaken in fact. $\mathrm{He}$ may be ignorant in law. What he does may be outside his jurisdiction - in fact or in law - but so long as he honestly believes it to be within his jurisdiction, he sould not be liable ... Nothing will make him liable except it be shown that he was not acting judicially, knowing that he had no jurisdiction to do it".

58 Juan Montero Aroca, Responsabilidad Civil del Juez del Estado por la actuación del Poder Judicial, Madrid, Tecnos, 1988, p. $24 / 25$.

${ }^{59}$ Enrico Righetti, La responsabilità civile del giudice nel diritto francese, Riv. Dir. Proc., 1991, p. 178.
60 Martine Lombard, La responsabilité du fait de la fonction juridictionnele et loi du 5.7.1972, Revue du Droit Public, 1975, n² 3, p. 585 .

61 Ibid., p. 598

62 André Laubadère, Traité de Droit Administratif Paris: LDGJ, 1990, tomo I, p. 829: "Une interprétatio littéralle des dispositions de l'article 11 de la loi du juillet 1972 priverait les victimes du bénéfice de responsabilite pour faute simple ou sans faute que les avait accordé la jurisprudence Giry. La Cour de Cassation n'a pas admis cette interprétation qui, dans u arrêt Cons. Pourcel ... a consacré la responsabilité san faute de l'État en cas de dommage causé, au cours d'une opération de police judiciaire...".

63 Jean Rivero, Droit Administratif, Paris: Dalloz, 1990, p. 380: "La responsabilité pour faute personelle n'est plus liée à la procedure de prise à partie, qui disparait".

64 Jean Vincent, La justice et ses institutions, Paris Dalloz, 3. ed., p. 430

${ }^{65}$ Ignacio Diez-Picazo Giménez, Appunti sulla responsabilità dello Stato in Spagna: il c. d. funzionamento anormale dell'amministrazione della giustizia RTDPC, 1990, ano 44, n 1/2, p. 581.

66 Ignacio Díez-Picazo Giménez, Appunti ..., p. 592

${ }^{67}$ José Almagro Nosete, Responsabilidad judicial, Cór doba: El Almendro, 1984, p. 85

${ }^{68}$ Luis Martín Rebollo, Jueces y Responsabilidad de Estado, Madrid: Centro de Estudios Constitucionales, 1983, p. 140/142.

${ }^{69}$ Luis Martín Rebollo, Jueces ..., p. 150/157.

70 Ignacio Díez-Picazo Giménez, Appunti ..., p. 594.

${ }^{71}$ No Brasil, considerando que a responsabilidade por ato judicial tem regulação restritiva, a responsabilidade pelos danos causados fora da atividade do juiz e dos seus auxiliares no processo deve ser regulada pelo princípio geral da administração pública (art. 37, $\S 6^{\circ}$ bens no depósito judicial, a colisão de veículo do serviço da justiça, etc.

72 Luis Martín Rebollo, Jueces ..., p. 158/160

73 Darcy Azambuja, Teoria Geral do Estado, Porto Alegre: Editora Globo, 1955, p. 53.

74 Pinto Ferreira, Teoria Geral do Estado, São Paulo: Saraiva, 1975, v. I, p. 207

75 Giogio Del Vecchio, Teoria do Estado, São Paulo: Saraiva, 1957, p. 39.

76 Léon Duguit, Traité de Droit Constitutionnel, I/282: "Si la souveraineté est une realité, elle ne se manifeste pas d'une manière plus intense dans l'acte manifeste pas d une manière plus intense dans
juridictionnel que dans l'acte administratif...".

77 Ac. do STF, de 19.7.1948, na RDA v. 40, p. 42: "O Estado responde civilmente pelo dano causado em vi tude de ato praticado com fundamento em lei declarada inconstitucional".
78 Pinto Ferreira, Teoria Geral do Estado, v. II, p. 212. ${ }^{9}$ Código de Processo Civil, art. 467 - "Denomina-s coisa julgada material a eficácia, que torna imutável indiscutível a sentença, não mais sujeita a recurso or Cinário on extroordinário". $\mathrm{Na}$ Lei de Introducão Código Civil (Dec Lei 4.657, de 4.9.42), constava ao Art 60 $\$ 3^{\circ}$ : "Chama 4.657 co julgada art ${ }^{80}$ Código de Processo Civil, art. 468 - "A sentença, que jugar total ou parcialmente a lide, tem força de lei no limites da lide e das questões decididas".

${ }^{81}$ Código de Processo Civil, Art. 301, $\$ 1^{\text {o: }}$ "Verifica-se litispendência ou a coisa julgada quando se reproduz ação anteriormente ajuizada". Art. 471: "Nenhuna juiz decidiŕ novame as questóes í decidids, ma juiz à mesma lide, salvo...".

${ }^{82}$ Pontes de Miranda, Comentários ao CPC, São Paulo: Ed. Forense, 1974, v. V, p. 146/147.

83 Carlos Alberto Parellada, Daños en la actividad judicial e informática desde la responsabilidad profesional, Buenos Aires: Astrea, 1990, p. 166: "A remoção da coisa julgada é necessária para poder propor ação de responsabilidade contra o magistrado interveniente no processo danoso e contra o Estado.

${ }^{84}$ Moacyr Amaral Santos, Comentários ao CPC, Rio: Forense, 1982, v. IV, p. $443 / 444$

85 Philippe Ardant, La responsabilité de l'État ..., p. 173.

${ }^{86}$ Mauro Cappelletti, Juízes irresponsáveis, Porto Alegre: Fabris, 1989, p. 33.

87 Celso Antonio Bandeira de Mello, Apontamentos sobre agentes e órgãos públicos, São Paulo: RT, 1975 , p. 3: "Todos aqueles que prestam serviço ao poder publico (Unizo, Estados e Municipios e respectivas autarquias), ou realizam atividade da alçada deste, podem ser designados agentes públicos"

Alberto Bittencourt Cotrim Neto, Da responsabilidade do Estado por atos de juiz em face da Constitujçào de 1988, Ajuris, 1992, v. 55, p. 76.

${ }^{89}$ Cretella Júnior, Responsabilidade do Estado por tos judiciais, RDA, 1970, v. 99, p. 13; Edmir Netto de Araújo, Responsabilidade do Estado por ato jurisdicio al, São Paulo: RT, 1981, p. 64; Maria Emília Mendes Alcântara, Responsabilidade do Estado por atos legis ativos e jurisdicionais, São Paulo: RT, 1988, p. 29 joão Sento Sé, Responsabilidade civil do Estado po atos judiciais, São Paulo: José Bushatsky, 1976, p. 60. ${ }^{90}$ Ada Pellegrini Grinover, A responsabilidade do juiz brasileiro, "in" Estudos de direito processual em home nagem a José Frederico Marques, São Paulo: Saraiva, 1982, p. 10; Hélio Tornaghi, Comentários ao CPC, São Paulo: RT, 1974, v. I, p. 412.

91 Mário Moacyr Porto, Responsabilidade do Estado pelo atos dos seus juízes, Revista dos Tribunais, 1982, v. 563, p. 9. 92 Giuseppe Chiovenda, Instituições de Direito Processual Civil, São Paulo: Saraiva, 1965, v. II. p. 3. 
93 Francesco Carnelutti, Sistema di Diritto Processuale Civile, I/131 e seg.

${ }^{94}$ Eduardo J. Couture, Fundamentos del Derecho Procesal Civil, Buenos Aires: Depalma, 1966, p. 40.

95 Galeno Lacerda, Comentários ao CPC, Rio: Forense 1980 , v. VIII, tomo I, p. 22/23.

96 Celso Agrícola Barbi, Comentários ao CPC, Rio: Forense, 1975, v. I, tomo I, p. 27/28: "A jurisdição não compreende apenas a função de decidir qual o direito, mas a atividade de tornar efetivo o direito reconhecido (processo de execucão) e de acautelar o direito de quem vencer a demanda (processo cautelar)".

97 Ovídio Baptista da Silva, Teoria Geral do Processo Civil, Porto Alegre: LEJUR, 1983, p. 48: "A jurisdição voluntária é uma autêntica atividade administrativa exercida pelo juiz".

${ }_{98}$ Adroaldo Furtado Fabricio, Comentários ao CPC Rio: Forense, 1980, v. VIII, tomo III, p. 4.

99 Giuseppe Chiovenda, Instituições de Direito Processual Civil, v. II, p. 16.

${ }^{100}$ Jaun Montero Aroca, Responsabilidad civil del juez y del Estado por la actuación del poder judicial, Madrid, Tecnot, 1988, p. 105.

101 A culpa grave ainda se há de fazer presente nas hipóteses expressamente reguladas em disposiçōes esparsas, como acontece nos artigos 294, 420, 421 e 1552 do Código Civil, e no artigo 4\%, "d", combinado com o artigo $6^{\circ}$, da Lei 4.898, de 9.12.1965.

102 Washington de Barros Monteiro, Curso de Direito Civil, São Paulo: Saraiva, 1960, p. 284. Pontes de Miranda dá o exemplo: "O juiz fundou o julgamento na afirmação de que uma das escrituras públicas cotinha a clausula da retrovenda, mas ele sabia que a escritura
pública era falsa" (Comentários ao CPC, v. II, p. 395). 103 Mário Júlio de Almeida Costa, Direito das Obrigações, Coimbra: Coimbra Editora, 1984, p. 382.

104 Clóvis Bevilaqua, Código Civil, Rio: Livraria Francisco Alves, 1959, v. I, p. 272.

105 Roberto de Ruggiero, Instituições de Direito Civil, São Paulo: Saraiva, 1958, v. 3, p. 123.

106 Emilio Betti, Teoria general del negocio jurídico, Madrid: Ed. Rev. de Der. Privado, s/d, p. 339.

107 Carlos Mário da Silva Velloso, Problemas e soluções na prestação da Justiça, Rev. dos Tribunais, v. 664, es na prestação da Justiça, Rev. dos Tribunais, v. 664,
p. 228: É claro que não seria possivel o juiz ser responp. 228: É claro que náo seria possivel o juiz ser respon-
sabilizado pela má interpretação que empreste à lei. Se isso fosse possivel, teríamos tirado do juiz a sua indeisso fosse possivel, teriamos tirado do juiz a sua inde-
pendência. Todavia, no que toca ao juiz indolente, pendência. Todavia, no que toca ao juiz indolente,
tardinheiro, que, injustificadamente, nào cumpre prazos, que adia audiências, que retarda atos de oficio, que não reside na sua comarca, penso que já é hora de não reside na sua comarca, penso que ja e hora de
pugnarmos, para esse mau juiz, um sistema de responsabilização em termos civis ... É necessário que o sistema seja aperfeiçoado, alargando-se o campo da responsabilidade civil do magistrado nos casos atrás mencionados". de demora excessiva para julgar uma causa, imputável ao magistrado" (José Agusto Delgado, Poderes, deveres e responsabilidade do juiz, Rev. Forense, 1988, v. 301, p. 335).

121 Eduardo Garcia Enteria, Curso de Derecho Administrativo, Madrid: Ed. Civitas, 1986, v. I, p. 351

122 Pontes de Miranda, Tratado de Direito Privado, Rio: Borsoi, 1966, v. 53, p. 94.

123 Carlos Mário da Silva Velloso, Responsabilidade Civil do Estado, Rev. de Informação Legislativa, p. 245: "A denunciação não causaria, ao que penso, prejuízo ao direito do autor da demanda ... O STF, entretanto, não tem entendido da mesma forma".

\section{Bibliografia Q}

Aguiar Dias, José de. Da responsabilidade civil. Rio: Forense, 1979.

Alcântara, Maria Emília Mendes. Responsabilidade do Estado por atos legislativos e jurisdicionais. São Paulo: Editora Revista dos Tribunais, 1988.

Almeida Costa, Mário Júlio de. Direito das Obrigafóes. Coimbra: Coimbra Editora, 1984

Amaral Santos, Moacyr. Comentários ae CPC. Rio: Forense, 1982.

Araújo, Edmir Neto de. O Estado Juiz e sua responsabilidade. Boletim de Direito Administrativo, jan. 1986.

---. Responsabilidade do Estado por ato jurisdicional. Revista dos Tribunais, São Paulo, 1981.

Ardant, Philippe. La Responsabilité de l'État du fait de la fonction juridictionelle. Paris: LGDJ, 1956.

Azambuja, Darcy. Teoria Geral do Estado. Porto Alegre: Editora Globo, 1955.

Bandeira de Mello, Celso Antonio. Apontamentos sobre agentes e órgãos públicos. Revista dos Tribunais, São Paulo, 1975.

---. Responsabilidade patrimonial da administração por atos administrativos. Revista de Direito Administrativo.

Barbi, Celso Agrícola. Comentários ao CPC. Rio: Forense, 1975.

Barbosa, Rui. Obras Completas, v. XXV, t. V, p. 178, parecer de 14.3.1898; Revista dos Tribunais, v. 133, p. 438, parecer de 18.5 .1900

Barros Monteiro, Washington de. Curso de Direito Civil. São Paulo: Saraiva, 1960.

Betti, Emilio. Teoria general del negocio jurídico. Rev. de Der. Privado, Madrid, s/d.

Bevilaqua, Clóvis. Código Civil. Rio: Livraria Francisco Alves, 1959.

Cahali, Iussef Said. Responsabilidade civil do Estado. São Paulo: Editora Revista dos Tribunais, 1982.
Cappelletti, Mauro. Juizes irresponsáveis. Porto Alegre: Fabris, 1989.

Carlin, Volnei Ivo. A responsabilidade civil do Estado resultante do exercício das funcões jurisdicionais. Revista dos Tribunais, São Paulo, 1982

Cavalcanti, Amaro. Responsabilidade Civil do Estado. Rio: Borsoi, ed. 1957.

Chiovenda, Giuseppe. Instituifõos de Direito Processual Civil. São Paulo: Saraiva, 1965.

Cotrim Neto, Alberto Bittencourt. Da responsabilidade do Estado por atos de juiz em face da Constituição de 1988. Revista da Associąáa dos Juizes do Rio Grande do Sul, 1992, v. 55.

Couto e Silva, Clóvis do. Principes Fondamentaux de la responsabilité civile en Droit brésilien en compasś Porto Alegre, Liçōes na Universidade de Paris Xn!, datilografado, 1988.

--. Le droi civil brésilien - Apergu bistorique et perspectives d'avenir (Lições na Universidade de Florença). Porto Alegre, datilografado, 1986

Couture, Eduardo J. Fundamentos del Derecho Procesal Civil. Buenos Aires: Depalma, 1966.

Cretella Júnior. Responsabilidade do Estado por atos judiciais. Revista de Direito Administrativo, 1970, v. 99.

Delgado, José Augusto. Responsabilidade civil do Estado pela demora na prestação jurisdicional. Revista de Processo, 1985.

-.-. Poderes, deveres e responsabilidade do juiz. Revis ta Forense, Rio: 1988, v. 301.

Del Vecchio, Giogio. Teoria do Estado. São Paulo: Saraiva, 1957.

Díez-Picazo Giménez, Ignacio. Appunti sulla responsabi lita dello Stato in Spagna: il c.d. funzionamento anormale dell'amministrazione della giustizia. Rivista Trimestrale di Diritto u Procedura Civile, 1990, ano $44, \mathrm{n}^{\mathrm{O}} 1 / 2$.

Duez, Paul. La responsabilité de la puissance publique. Paris: Dalloz, 1927

Enteria, Eduardo Garcia. Curso de Derecho Administrativo. Madrid: Ed. Civitas, 1986

Fabricio, Adroaldo Furtado. Comentários ao CPC. Rio Forense, 1980.

Falcão, Alcino Pinto. Responsabilidade patrimonial das pessoas jurídicas de Direito Público. Revista de Direito Administrativo, v. 11, p. 45.

Figurelli, Adelaide N. La responsabilità discplinare del giudice: il dibattito più recente e la prospettiva de soluzioni nuove. Rivista Trimestrale di Diritto Procedura Civile, 1982.

Grinover, Ada Pellegrini. A responsabilidade do juiz brasileiro. In: Estudos de direito processual em bomenagem a José Frederico Marques. São Paulo: Saraiva, 1982 
Iturraspe, Jorge Mosset. Responsabilidade Civil. Buenos Aires: Editorial Hammurabi, 1992.

Lacerda, Galeno. Comentários ao CPC. Rio: Forense, 1980.

Laubadère, André. Traité de Droit Administratif. Paris: LDGJ, 1990.

Lessa, Pedro: Do Poder Judiciário. Rio: Livraria Francisco Alves, 1915.

Lévy, Denis. La responsabilité de la puissance publique et de ses agents en Angleterre. Paris: LDGJ, 1957.

Lombard, Martine. La responsabilité du fait de la fonction juridictionnele et la loi du 5.7.1972. Revue $d u$ Droit Public, 1975, $\mathrm{n}^{\mathrm{O}} 3$.

Martins Jr., J. Isidoro. História do Direito Nacional. Rio: Empresa Democrática Editora, 1895.

Maximiliano, Carlos. Comentários à Constituição Brasileira (1946). Rio: Freitas Bastos, 1954.

Meirelles, Hely Lopes. Direito Administrativo Brasileiro. São Paulo: Editora Revista dos Tribunais, 1989.

Nequete, Lenine. $O$ poder judiciário no Brasil - Crônica dos tempos coloniais. Porto Alegre: Ed. Ajuris, s.d.

Nosete, José Almagro. Responsabilidad judicial. Córdoba: Ed. El Almendro, 1984

Parellada, Carlos Alberto. Daños en la actividad judicial e informática desde la responsabilidad profesional. Buenos Aires: Astrea, 1990.

Picardi, Nicola. Problemi attuali dela responsabilità del giudice. Rivista Trimestrale di Diritto u Procedura Civile, $1979, \mathrm{n}^{\circ} 4$

Pimenta Bueno. Direito Público Brasileiro e análise da Constituigão do Império. Rio: Ministério da Justiça, 1958.

Pinto, Nelson Luiz Guedes Ferreira. Teoria Geral do Estado. São Paulo: Saraiva, 1975.

---. A responsabilidade civil do Estado por atos judiciais. Cadernos de Pós-Graduação da Universidade Federal de Minas Gerais - Faculdade de Direito, 1977.

Pontes de Miranda. Comentários ao CPC. São Paulo: Ed. Forense, 1974.

--. Tratado de Direito Privado. Rio: Borsoi, 1966.

Porto, Mário Moacyr. Responsabilidade do Estado pelos atos dos seus juizes. Revista dos Tribunais, São Paulo, 1982, v. 563

Rebollo, Luiz Martín. Jueces y Responsabilidad del Estado Madrid: Centro de Estudios Constitucionales, 1983.

Righetti, Enrico. La responsabilità civile del giudice nel diritto francese. Riv. Dir. Proc., 1991.

Rivero, Jean. Droit Administratif. Paris: Dalloz, 1990.

Ruggiero, Roberto de. Instituiçóes de Direito Civil. São Paulo: Saraiva, 1958.

Salazar, Alcino de Paula. Responsabilidade do poder público por atos judiciais. Rio: Canton \& Reile, 1941.
Sé, João Sento. Responsabilidade civil do Estado por atos judiciais. São Paulo: José Buschatsky, 1976.

Silva Filho, Artur Marques da. Juízes irresponsáveis. Revista dos Tribuinais, 1991, v. 674, p. 70.

Silva, Juary C. Responsabilidade civil do Estado por atos jurisdicionais. Revista dos Tribunais, São Paulo, 1965. Silva, Ovídio Baptista da. Teoria Geral do Processo Civil. Porto Alegre: LEJUR, 1983

Souza, José Guilherme de. A responsabilidade civil do Estado pelo exercício da atividade judiciária. Revista dos Tribunais, São Paulo, 1990

Starck, B. Essai d'une théorie générale de la responsabilité civile considerée en sa double fonction de garantie et do peine privé. Paris: Rodstein, 1947.

Suannes, Adauto. A responsabilidade do juiz pelo erro judiciário. Cadernos de Advocacia Criminal, dez. 1988 , v. 1, n. 6.

Má prestação judicial e indenização correspondente. Revista Brasileira de Ciências Criminais, Re vista dos Tribunais, $\mathrm{n}^{\circ}$ especial de lançamento.

Tawil, Guido Santiago. La responsabilidad del Estado y de los magistrados y funcionários judiciales por el mal funcionamiento de la administración de justicia. Buenos Aires: Depalma, 1989

Tornaghi, Hélio, Comentários ao CPC. São Paulo: Ed. Revista dos Tribunais, 1974.

Trocker, Nicolò. La responsabilità del giudice. Rivista Trimestrale di Diritto u Procedura Civile, 1982.

Velloso, Carlos Mário da Silva. Problemas e solucõoes na prestação da Justiça. Revista dos Tribunais, 1991 v. 664

--. Responsabilidade Civil do Estado. Revista de In formaşãa Legislativa, 1987, nº 96.

Vincent, Jean. La justice et ses institutions. 3.ed. Paris: Dalloz, s.d.

Walker \& Walker. The English Legal System. London Butter Worths, 1980

Wambier, Luiz Rodrigues. A responsabilidade civil do Estado decorrente dos atos jurisdicionais. Revista dos Tribunais, São Paulo, 1988, v. 633, p. 34.

\section{El fondo ad hoc creado en Francia para indemnización de las víctimas del contagio del SIDA por transfusiones sanguíneas (Ley del 31 de diciembre de 1991).}

\section{Luis O. Andorno}

Professor Titular de Direito Civil da Facultad de Derecho de la

Universidad Nacional de Rosário - Argentina.

Doutor em ciencias jurídicas y sociales pela Facultad de Ciencias Jurídicas

y Sociales de la Universitad Nacional del Litoral (Santa Fé - Argentina).

SUMARIO

I. Introducción; II. El Fondo ad hoc creado en Francia por la ley del 31 de diciembre de 1991; III. El contenido de la indemnización prevista en dicha ley; IV. Los recursos previstos por la ley no 91.1406/92; V. Conclusiones.

\section{Introducción}

El denominado Síndrome de Inmunodeficiencia Adquirida SIDA se ha convertido en la actualidad en uno de las mayores flagelos que debe soportar la Humanidad.

Lamentablemente se trata de una epidemia en continua expansión, sin que se haya descubierto hasta el presente remedio alguno que pueda contrarrestar sus efectos devastadores que acaban con la vida de los afectados por ella, aun cuando periódicamente los medios masivos de comunicación traigan algunas noticias alentadoras referidas a la posibilidad del descubrimiento de alguna vacuna que pueda resultar eficaz en la lucha contra dicha enfermedad, en tiempos tal vez no tan lejanos.

Según el informe producido por la Organización Mundial de la Salud en Ginebra, el 21 de mayo de 1993, catorce millones de personas han sido contaminadas por el vi rus de inmunodeficiencia humana, en adelante: VIH, desde que comenzó la epidemia, esperándose para el año 2.000 un número acumulado de sujetos infectados cercano a los cuarenta millones de personas.

Tales cifras resultam harto elocuentes en cuanto a la gravedad de este mal en crecien- te difusión geográfica en los distintos continentes y en lo tocante a la imprescindible nececidad de adoptar medidas rápidas y eficaces para impedir su avance con sus nefastas consecuencias.

Si bien en América, los países que cuentam con el mayor número de casos de SIDA son los EE. UU. y Brasil, también nuestro país registra una apreciable cantidad de enfermos, desgraciadamente en aumento, no solamente en los denominados grupos de riesgo: homosexuales y drogadictos, sino también en otras personas.

De allí por tanto también entre nosotros existe la imperiosa necesidad de tomar conciencia de la magnitud del flagelo a fin de obrar en consecuencia, procurando adoptar los remedios apropriados a tales efectos.

Al respecto resulta importante recordar que con fecha 14 de setiembre de 1990 , se promulgó en nuestro país la llamada Ley de lucha contra el Síndrome de Inmunodeficiencia Adquirida SIDA que lleva el $\mathrm{n}^{\circ}$ 23.798, cuyo artículo 10 dispone: "Declárase de interés nacional a la lucha contra el Sindrome de Inmunodeficiencia Adquirida, entendiéndose por tal a la detección e investigación de sus agentes causales, el diagnóstico y tratamiento de la enfermedad, su preven-

R. Fac. Direito UFRGS, Porto Alegre, 9(1): 41-47, nov. 1993 